\title{
The physical and chemical structure of the Oku-aizu geothermal system, Japan
}

\author{
YOJI SEKI \\ Mineral Resources Department, Geological Survey of Japan, Higashi 1-1-3, Tsukuba 305, Japan
}

(Received February 3, 1991; Accepted May 29, 1991)

The physical and chemical characteristics of the Oku-aizu geothermal system, northeast Japan, are reviewed, with these data used to construct a geochemical model of the system. The exploration of this area started in 1974, with a total of 39 wells being drilled through fiscal year 1990. A total of $509 \mathrm{t} / \mathrm{h}$ of dry steam $\left(165^{\circ} \mathrm{C}\right)$ was confirmed during the simultaneous production test, equivalent to about $55 \mathrm{MW}$ of electric power.

The bedrock of the production zones are Miocene formations composed mainly of rhyolitic lavas and pyroclastics. Pre-Tertiary basement unconformably underlie these formations. The uppermost portion of the system is comprised of a Quaternary lacustrine deposit which was penetrated by shallow rhyolite intrusions at 0.2 to $0.5 \mathrm{Ma}$. This lacustrine deposit is thought to be related to a subsidence structure.

Two different types of hydrothermal alteration are recognized. One is related to submarine volcanic activity in the Miocene, and is composed of chlorite and sericite. The other is a product of the present geothermal system, and has advanced argillic alteration zones at the surface and an argillic zone at depth. Alteration minerals observed in the advanced argillic zone are smectite and mordenite with a minor amount of sericite, alunite and kaolinite. Those in the argillic zone are smectite, interlayered illite-smectite, kaolinite, zeolite and K-feldspar. Anhydrite is common in the deeper portion of the system at higher temperature.

The highest measured temperature is $341^{\circ} \mathrm{C}$, and temperatures higher than $300^{\circ} \mathrm{C}$ are quite common in production zones. Isotherms at $-1200 \mathrm{~m} \mathrm{ASL}$ open to the SE, which may indicate the direction of the heat source. From the deepest drilled levels to about $-200 \mathrm{~m}$ ASL, the thermal gradient is small, indicating the existence of non-boiling convection over this depth range. The uppermost part of the convection cell is limited by a sealed zone caused by argillic alteration and a Miocene mudstone formation. The system is considered to have had little boiling in its natural state before exploration. However, it is presently boiling around geothermal wells due to the pressure drop caused by reservoir fluid discharge.

The composition of the reservoir fluid is characterized by high salinity (about $2 \mathrm{wt} \%$ ) and a large amount of non-condensible gas (about $1 \mathrm{wt} \% \mathrm{CO}_{2}$ and $250 \mathrm{mg} / \mathrm{kg} \mathrm{H}_{2} \mathrm{~S}$ ). This, as well as its very high underground temperature, is consistent with isotopic indications of a magmatic component to the discharge of the system. This idea is also concordant with the $\mathrm{B} / \mathrm{Cl}$ and $\mathrm{Br} / \mathrm{Cl}$ ratios.

Small amounts of base metal sulfide mineralization (pyrite, sphalerite, galena, chalcopyrite etc.) are present at the level of the production zone. This is considered to be a product of the present geothermal system, judging from its mode of occurrence. Significant concentrations of precious metals ( $\mathrm{Au} \leq 116$ $\mathrm{mg} / \mathrm{kg}, \mathrm{Ag} \leq 3.49 \mathrm{wt} \%$ ) were found in sulfide scales collected from surface two-phase lines.

\section{INTRODUCTION}

Thirty nine wells have been drilled up to early 1991 in and adjacent to the Oku-aizu geothermal system, located in Yanaizu town, Fukushima prefecture, northeast Japan (Fig. 1 and Table 1).
The system is now in the final stage of assessment prior to development by the Oku-aizu Geothermal Co., Ltd. (OAG) as an energy source.

The system is known for its highly productive geothermal wells, and also for base metal 


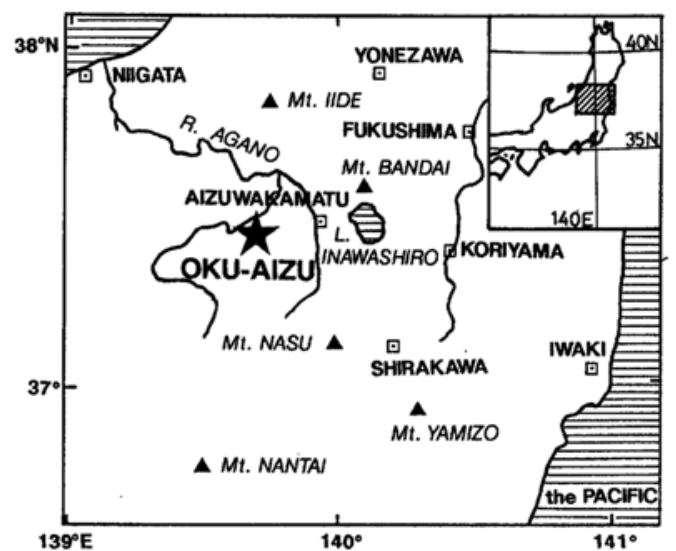

Fig. 1. Location of the Oku-aizu geothermal system. mineralization and precious metal-rich sulfide scaling. The salinity ( $\mathrm{NaCl}$ equiv. up to about 2 $\mathrm{wt} \%$ ) and reservoir temperature (often $>300^{\circ} \mathrm{C}$, maximum $341^{\circ} \mathrm{C}$ measured) are the second highest in Japan (after Fushime, a sea-water dominated system). The extensive drilling and discharge testing of wells by OAG to date has provided sufficient detail to make a basic interpretation of the physical and chemical structure of the system prior to exploitation. However, further study is necessary to establish the evolution of the geothermal system. The purpose of this paper is to provide an update on earlier published reports, largely by $\mathrm{OAG}$, and to integrate the

Table 1. Specifications of geothermal wells (OAG, pamphlet)

\begin{tabular}{|c|c|c|c|c|c|}
\hline Well & Purpose & Target & $\begin{array}{l}\text { W.H.E. } \\
\text { (m ASL) }\end{array}$ & $\underset{\text { (m) }}{\text { B.H.D. }}$ & $\begin{array}{l}\text { B.H.S. } \\
\text { (mm) }\end{array}$ \\
\hline OA-1 & structural survey & & 320 & 1005 & 78 \\
\hline OA-2 & ditto & & 472 & 1004 & 78 \\
\hline OA-3 & ditto & & 392 & 1500 & 100 \\
\hline OA-4 & ditto & & 345 & 1305 & 100 \\
\hline OA-5 & ditto & & 392 & 1006 & 75 \\
\hline OA-6 & environment. assess. & & 376 & 1500 & 80 \\
\hline OA-7 & ditto & & 363 & 1004 & 102 \\
\hline $84 N-1 t$ & exploration & OF & 376 & 2003 & 79 \\
\hline $84 \mathrm{~N}-2 \mathrm{t}$ & ditto & CFZ & 424 & 1507 & 101 \\
\hline $84 N-3 t$ & ditto & SFZ & 449 & 1845 & 79 \\
\hline $84 N-4 r$ & reinject. evaluation & $\mathrm{CFZ}$ & 424 & 712 & 76.2 \\
\hline $84 \mathrm{~N}-5 \mathrm{t}$ & exploration & TF & 357 & 1707 & 81 \\
\hline $85 \mathrm{~N}-6 \mathrm{~T}$ & product. evaluation & CFZ & 428 & 1655 & 215.9 \\
\hline $85 \mathrm{~N}-7 \mathrm{~T}$ & reservoir evaluation & & 377 & 659 & 215.9 \\
\hline $85 \mathrm{~N}-8 \mathrm{~T}$ & ditto & & 370 & 659 & 215.9 \\
\hline $85 \mathrm{~N}-9 \mathrm{~T}$ & ditto & & 460 & 701 & 215.9 \\
\hline $86 \mathrm{~N}-10 \mathrm{~T}$ & product. evaluation & CFZ & 426 & 1660 & 215.9 \\
\hline $86 \mathrm{~N}-11 \mathrm{~T}$ & ditto & SFZ & 415 & 1655 & 215.9 \\
\hline $86 \mathrm{~N}-12 \mathrm{t}$ & exploration & SFZ & 490 & 1574 & 101.0 \\
\hline $86 \mathrm{~N}-13 \mathrm{t}$ & ditto & KF & 418 & 1406 & 101.0 \\
\hline $87 \mathrm{~N}-14 \mathrm{~T}$ & product. evaluation & CFZ & 392 & 1560 & 215.9 \\
\hline $87 \mathrm{~N}-15 \mathrm{~T}$ & ditto & CFZ & 400 & 1860 & 215.9 \\
\hline $87 \mathrm{~N}-16 \mathrm{~T}$ & ditto & SFZ & 415 & 1758 & 215.9 \\
\hline $87 \mathrm{~N}-17 \mathrm{~T}$ & ditto & SFZ & 415 & 1661 & 215.9 \\
\hline $87 \mathrm{~N}-18 \mathrm{t}$ & exploration & OFZ & 413 & 1654 & 76.2 \\
\hline $88 \mathrm{~N}-19 \mathrm{R}$ & reinject. evaluation & OFZ & 401 & 1505 & 311.2 \\
\hline $88 \mathrm{~N}-20 \mathrm{R}$ & ditto & OFZ & 401 & 1459 & 311.2 \\
\hline $89 \mathrm{~N}-21 \mathrm{~T}$ & product. evaluation & CFZ & 400 & 2010 & 215.9 \\
\hline $89 \mathrm{~N}-22 \mathrm{~T}$ & ditto & CFZ(SE) & 443 & 2609 & 215.9 \\
\hline $90 \mathrm{~N}-23 \mathrm{P}$ & product. evaluation & CFZ & 400 & 1909 & 215.9 \\
\hline $90 \mathrm{~N}-24 \mathrm{P}$ & ditto & CFZ(SE) & 443 & 2610 & 215.9 \\
\hline $90 \mathrm{~N}-25 \mathrm{P}$ & ditto & CFZ(SE) & 508 & 2699 & 215.9 \\
\hline
\end{tabular}

Abbreviations: W.H.E., well head elevation; B.H.D., bottom hole depth; B.H.S., bottom hole diameter; CFZ, Chinoikezawa fault zone; SFZ, Sarukurazawa fault zone; OFZ, Oizawa fault zone; TF, Takiyagawa fault; KF, Kitanosawa fault; $O F$, Onogawara fault. 
physical and chemical characteristics of the system into an internally consistent model of the pre-exploitation system.

\section{DEVELOPMENT History}

Exploration of the Oku-aizu geothermal system commenced with a reconnaissance survey by Mitsui Mining and Smelting Co., Ltd. (MMSC) in 1974. Subsequently, the first-phase geological, geophysical and geochemical survey was conducted by the New Energy Development Organization (NEDO) from 1976 to 1977 . After a geophysical and geochemical survey by MMSC in 1981, the second- phase geological, geochemical and geophysical survey by NEDO was conducted from 1982 to 1983 . During this period, 13 core holes (290 to $1500 \mathrm{~m}$ depth) were drilled to determine the geological structure and heat flow. Some of these holes were the first to encounter a productive reservoir. In 1983, the Okuaizu Geothermal Co., Ltd (OAG) was established to carry out further exploration and assessment, and to undertake development. From 1984 to 1985, OAG carried out geological, geophysical and geochemical surveys, and drilled five cored wells and four other wells (cuttings only). Production tests of 18 to 119 days for each productive well were also conducted. From 1986 to 1989,13 more wells (all with cuttings) were drilled, with 30 to 109 day production tests conducted for each production well (Nitta et al., 1987; Ishihara, 1988 and recent company pamphlet). Table 1 lists targets and characteristics of 33 wells.

A total of $509 \mathrm{t} / \mathrm{h}$ of dry steam at about $165^{\circ} \mathrm{C}$ from nine wells was confirmed during a three month simultaneous production test, from December, 1989, to February, 1990 (Nitta et al., 1990). Three additional production wells were drilled during fiscal year 1990.

The Okuaizu Geothermal Co., Ltd. originally planned to develop $55 \mathrm{MW}$ from the system (OAG, explanation pamphlet). As a result of an independent feasibility study from 1986 to 1988 , $55 \mathrm{MW}$ of power production for 30 years was predicted, without reservoir pressure support by reinjection. Further production wells have been added after that reservoir evaluation. The target of power capacity has now been increased to 65 MW based on the results of steam discharge from new production wells, confirmed by the latest production tests held in 1990 (Nitta et al., 1990).

\section{Geological Setting and Surficial Features}

\section{Geology, stratigraphy and structure}

The Oku-aizu area is located in the "Green Tuff region", characterized by Neogene submarine volcanic activity, and is about $50 \mathrm{~km}$ west of the present volcanic front. Numazawakazan is the nearest Quaternary volcano $(10 \mathrm{~km}$ west), and was active about 5000 years ago (Kato et al., 1984).

The basement is thought to be pre-Tertiary granodiorite and/or sedimentary rocks, although it has not been reached by drilling in this area (Nitta et al., 1987). Miocene formations (Oh-hizawa, Takizawagawa, Ogino and Urushikubo Formation) consist of rhyolitic lavas and pyroclastic rocks intercalated with clastic rocks, plus minor basaltic rocks, and probably unconformably overlie the basement. Pliocene dacitic pumice tuff intercalated with clastic rocks (Fujitoge Formation) rest unconformably on the Miocene formations. Pleistocene lacustrine sediments (Sunagohara Formation) unconformably covers the Pliocene formation in a limited ring-shaped area about $3 \mathrm{~km}$ in diameter surrounding rhyolite lava domes (Yunotake rhyolite; Fig. 2). These rhyolite lava domes are shallow level intrusives into the lacustrine sediments (NEDO, 1985; Nitta et al., 1987). The unconformity between the Quaternary and underlying formations is generally steep and in some places has an associated poorly-sorted basal breccia from the adjacent underlying strata (Komuro, 1978). The distribution of the lacustrine sediments is concordant with the large depth to basement (below $-2500 \mathrm{~m}$ ASL) inferred from gravity survey (Fig. 3; Nitta et al., 1987). The surficial distribution of these forma- 

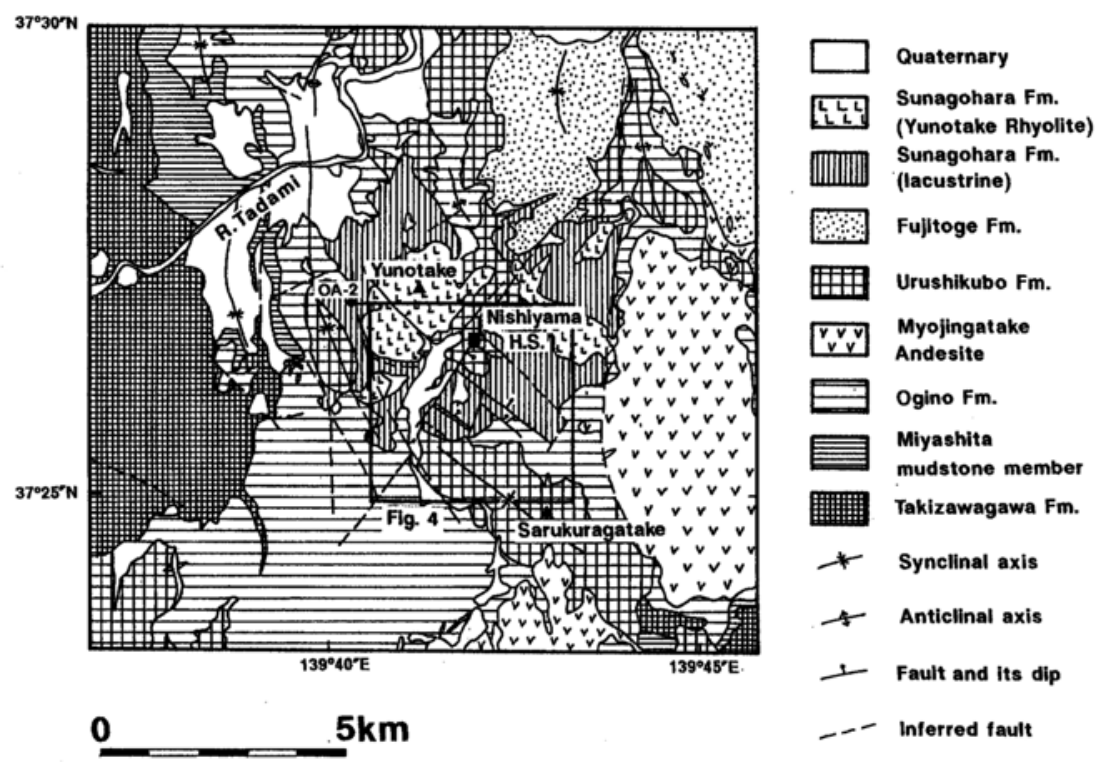

Fig. 2. Regional geology of the Oku-aizu geothermal system (Nitta et al., 1987). Area in the box is shown in Fig. 4.

Table 2. A regional stratigraphic column of the Oku-aizu district (Nitta et al., 1987)

\begin{tabular}{|c|c|c|c|c|}
\hline $\begin{array}{l}\text { Geologic } \\
\text { Age }\end{array}$ & Formation & Lithology & $\begin{array}{c}\text { Thick. } \\
\text { (m) }\end{array}$ & $\begin{array}{l}\text { Absolute } \\
\text { Age (Ma) }\end{array}$ \\
\hline \multirow[t]{2}{*}{ Quat. } & $\begin{array}{l}\text { Numazawa } \\
\text { Pyroclastics }\end{array}$ & Dacitic pyroclastic flow, tuff and scoria & & 0.005 \\
\hline & Sunagohara & $\begin{array}{l}\text { Glassy and perlitic rhyolite, tuffaceous sandstone, } \\
\text { siltstone and conglomerate }\end{array}$ & $>150$ & $0.2-0.9$ (Rhy.) \\
\hline Plioc. & Fujitoge & Sandstone, rhythmic alternation of tuffaceous and- & 300 & $3.2 \pm 0.3$ (Rhy.) \\
\hline \multirow[t]{4}{*}{ Mioc. } & Urushikubo & $\begin{array}{l}\text { stone and mudstone, pumice tuff and conglomerate } \\
\text { Sandstone, siltstone, mudstone, conglomerate, tuff } \\
\text { breccia, pumice tuff, basaltic pyroclastics, and } \\
\text { rhyolite lava }\end{array}$ & $200-600$ & $5.3 \pm 0.4$ (Rhy.) \\
\hline & Ogino & $\begin{array}{l}\text { Rhyolitic pyroclastics and lava, andesitic-basalitic } \\
\text { pyroclastics, and mudstone (Miyashita mudstone member) }\end{array}$ & $200-300$ & $8.8 \pm 0.4$ (And.) \\
\hline & Takizawagawa & Rhyolitic pyroclastics and lava & $1000-1300$ & \\
\hline & Oh-hizawa & Conglomerate, san'dstone and rhyolite & $500-600$ & \\
\hline
\end{tabular}

tions is shown in Fig. 2 and the detailed stratigraphy is described in Table 2 .

The area of the lacustrine sediments is considered to coincide with a collapse basin (Hayakawa et al., 1977, Komuro, 1978 and Suzuki et al., 1986). Competing ideas have been presented as to the cause of the collapse. The first is a local tectonic subsidence (Hayakawa et al., 1977; Suzuki, 1986). The second is a magmatic intrusion-related collapse (not a caldera collapse but rather a keystone graben structure; Komuro, 1978; MITI, GSJ, 1978). The third is a caldera collapse (Yamamoto, in press). Further detailed lithologic and volcanologic study is necessary to resolve this question. 


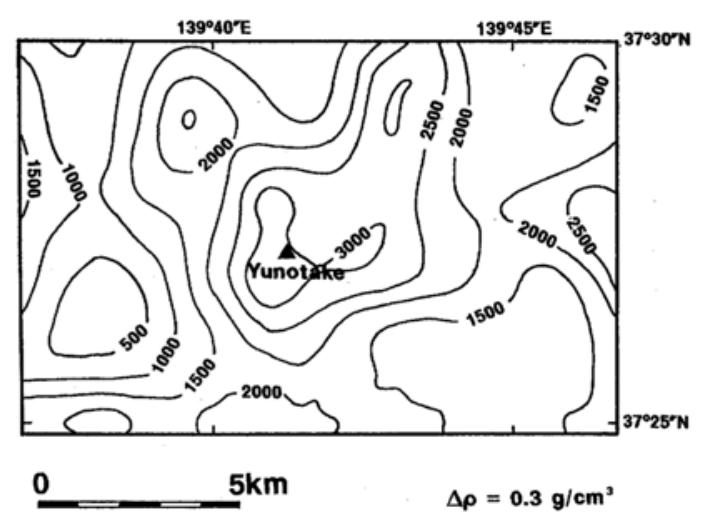

Fig. 3. Depth below surface (in $m$ ) of the pre-Tertiary basement inferred from gravity anomalies (Nitta et al., 1987).

The hydrological system is strongly controlled by a tectonic fracture system (Fig. 4). The production area is composed of two major fault zones called the Chinoikezawa and Sarukurazawa fault zones. Both strike NW, and dip $76^{\circ}$ and $83^{\circ} \mathrm{NE}$, respectively, with swarms of associated open-space fractures (Nitta et al., 1987). There is another major fracture zone called Oizawa fault zone, located about $1 \mathrm{~km} \mathrm{NE}$ of the Sarukurazawa fault zone. It strikes nearly

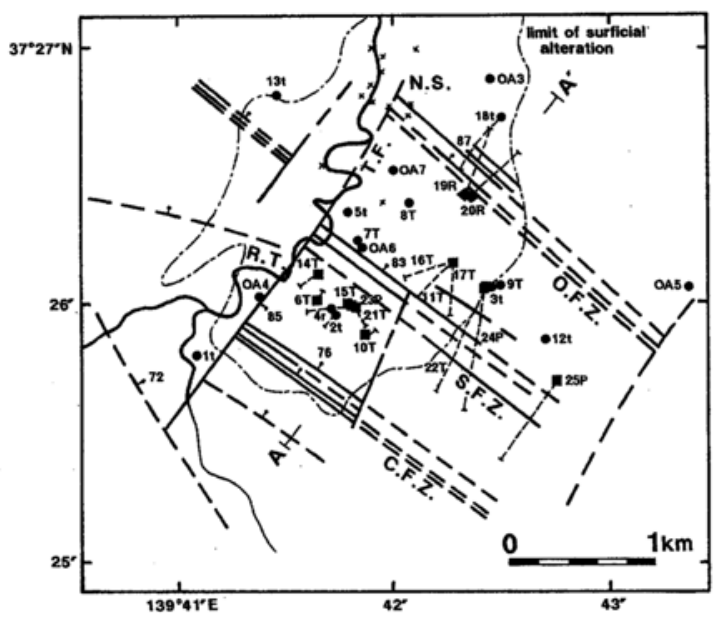

Fig. 4. Distribution of major fracture systems, hot springs and area of surficial alteration, and geothermal wells (compiled from Nitta et al., 1987 and OAG, unpublished data). Abbreviations: C.F.Z., Chinoikezawa fault zone; S.F.Z., Sarukurazawa fault zone; O.F.Z., Oizawa fault zone; T.F., Takiyagawa fault; N.S., Nishiyama spa; R.T., River Takiyagawa. Symbols: $\longrightarrow \perp^{76}$, fault and dip; - —, inferred fault; - geothermal well (production); $\downarrow$, geothermal well (reinjection); •, geothermal well (others); $\times$, hot spring; -- - border of surficial alteration area.

Table 3. Analytical results of hot spring waters in the Nishiyama spa (Hirukawa et al., 1981)

\begin{tabular}{|c|c|c|c|c|c|c|c|c|}
\hline $\begin{array}{l}\text { No. } \\
\text { Date of analysis } \\
\text { Temperature }\left({ }^{\circ} \mathrm{C}\right) \\
\text { pH }\end{array}$ & $\begin{array}{c}\text { NYC-6 } \\
1955 / 01 / 20 \\
93.0 \\
8.1\end{array}$ & $\begin{array}{c}\text { NYC-7 } \\
51 / 01 / 16 \\
68.0 \\
8.1\end{array}$ & $\begin{array}{c}\text { NYC-8 } \\
61 / 11 / 22 \\
79.0 \\
7.0\end{array}$ & $\begin{array}{c}\text { NYC-9 } \\
51 / 01 / 12 \\
71.0 \\
8.0\end{array}$ & $\begin{array}{c}\text { NYC-10 } \\
51 / 01 / 16 \\
61.0 \\
7.8\end{array}$ & $\begin{array}{c}\text { NYC-11 } \\
51 / 01 / 20 \\
65.0 \\
8.2\end{array}$ & $\begin{array}{c}\text { NYC-12 } \\
51 / 01 / 12 \\
77.0 \\
8.3\end{array}$ & $\begin{array}{c}\text { NYC-13 } \\
56 / 11 / 15 \\
67.0 \\
6.6\end{array}$ \\
\hline \multicolumn{9}{|c|}{ Component (mg/kg) } \\
\hline $\mathrm{Na}^{+}$ & 1292 & 1562 & 1640 & 1635 & 1679 & 1449 & 1472 & 966 \\
\hline $\mathrm{K}^{+}$ & 169 & 340 & 165 & 185 & 433 & 118 & 167 & 117 \\
\hline $\mathrm{Mg}^{2+}$ & 2.3 & 30.7 & 4.8 & 5.7 & 29.7 & 5.3 & 10.2 & 1.2 \\
\hline $\mathrm{Ca}^{2+}$ & 50.4 & 51.8 & 31.9 & 42.8 & 58.1 & 57.5 & 65.9 & 26.5 \\
\hline $\mathrm{NH}_{4}^{+}$ & - & 0.2 & 0.51 & 0.4 & 0.2 & 6.2 & 0.5 & - \\
\hline $\mathrm{Fe}^{2+}$ & 0.2 & 8.0 & 0.04 & - & 4.7 & 1.4 & 1.2 & 18.8 \\
\hline $\mathrm{Al}^{3+}$ & 2.3 & - & 1.45 & 0.3 & - & 1.4 & 0.7 & 2.7 \\
\hline $\mathrm{Mn}^{2+}$ & - & - & 0.39 & 0.8 & - & - & - & 0.56 \\
\hline $\mathrm{Cl}^{-}$ & 1630 & 2215 & 2438 & 2226 & 2297 & 1886 & 2139 & 1492 \\
\hline $\mathrm{Br}^{-}$ & - & - & 0.36 & - & - & - & - & - \\
\hline $\mathrm{I}^{-}$ & - & - & 0.68 & - & - & - & - & - \\
\hline $\mathrm{F}^{-}$ & 0.08 & - & 0.90 & - & - & - & - & - \\
\hline $\mathrm{SO}_{4}^{2-}$ & 263 & 302 & 290 & 314 & 338 & 276 & 313 & 187 \\
\hline $\mathrm{HCO}_{3}^{-}$ & 732 & 798 & 78.3 & 417 & 1085 & 578 & 302 & 80.1 \\
\hline $\mathrm{CO}_{3}^{2-}$ & - & 5.8 & 0.03 & 68.2 & - & 42.7 & 20.0 & - \\
\hline $\mathrm{SiO}_{2}$ & 130 & 149 & 134 & 132 & 173 & 134 & 101 & 179 \\
\hline $\mathrm{H}_{2} \mathrm{~S}$ & - & - & 2.9 & - & - & - & - & 5.1 \\
\hline
\end{tabular}


parallel to the productive fault zones and dips $87^{\circ} \mathrm{NE}$. The temperature in the deeper part of this zone is much lower (about $100^{\circ} \mathrm{C}$ ) than that of the productive zones, leading to the decision to use this fault zone for reinjection.

\section{Thermal manifestations}

Several hot springs are located within the area (Fig. 4), some of which have temperatures close to boiling. Some weak gas discharges composed of $\mathrm{CO}_{2}$ and/or $\mathrm{H}_{2} \mathrm{~S}$ are also present.

Of the 15 total hot springs, three have temperatures above $90^{\circ} \mathrm{C}$; they constitute the Nishiyama spa. Although the confirmed flow is $267 \mathrm{l} / \mathrm{min}$., the total flow is thought to be much more, as considerable leakage into the local river occurs (Nitta et al., 1987). The hot springs discharge dilute $\mathrm{NaCl}$-type waters $\left(\mathrm{Na}^{+}: 966\right.$ to $1679 \mathrm{mg} / \mathrm{kg}, \mathrm{Cl}^{-}: 1492$ to $2438 \mathrm{mg} / \mathrm{kg}$ ) with low $\mathrm{CO}_{2}$ (total $\mathrm{CO}_{2}$ : several $100 \mathrm{mg} / \mathrm{kg}$ ) and $\mathrm{H}_{2} \mathrm{~S}$ (several mg/kg) (Hirukawa et al., 1981, Table 3). Most hot springs are located where the Oizawa fault zone intersects the Takiyagawa fault zone, about $1 \mathrm{~km}$ north of the productive zone.

Several discharges of $\mathrm{CO}_{2}$ with $\mathrm{H}_{2} \mathrm{~S}$ occur mainly along the Chinoikezawa fault zone where the highest subsurface temperatures are recorded. There are also a few gas discharges along the Takiyagawa fault and the Sarukurazawa fault zone (Nitta et al., 1987).

\section{Hydrothermal Alteration}

\section{Regional alteration in the Miocene}

The Oku-aizu geothermal system is largely hosted by rocks affected by regional alteration during the Miocene (the "'Green-Tuff'). In the Aizu district, which surrounds the Oku-aizu geothermal system, the following succession of regional alteration has been recognized from surface downwards; fresh glass, clinoptilolitemordenite, analcime, laumontite, and albitechlorite-sericite zones (Hayakawa et al., 1977). In the Oku-aizu system itself, chlorite-sericite alteration has affected the greater part of the Miocene formations, mostly composed of rhyolitic lava, tuff and tuff breccia (for example,
OA-2 (Fig. 5a), OA-5 (Fig. 5b) and OA-6, compiled from NEDO, 1985). A significant portion of this chlorite-sericite zone is considered to be a product of the early regional alteration, though distinguishing this from similar alteration related to the present system is quite difficult (Nitta et al., 1987).

\section{Present system-related alteration}

Argillic to advanced argillic alteration occurs at shallow levels and anhydrite at deeper, higher temperature levels, and are considered to be related to the present geothermal system. In addition, carbonate minerals are commonly observed in most wells in the system, also related to present hydrothermal activity.

Argillic alteration occurs mainly in the Sunagohara Formation, a Quaternary lacustrine deposit composed of tuffaceous sandstone and siltstone, and in the Urushikubo Formation, composed of tuffaceous sandstone, siltstone, mudstone, rhyolitic glassy tuff, pumiceous tuff, and lava. In some wells ( $86 \mathrm{~N}-12 \mathrm{t}, 87 \mathrm{~N}-17 \mathrm{~T}$ (Fig. 5d), $89 \mathrm{~N}-22 \mathrm{~T}$ (Fig. 5e) and 90N-24P), this alteration is also seen in the Ogino and Takizawagawa Formations, composed mainly of rhyolitic lava, tuff and tuff breccia, with some Miocene mudstone.

The alteration minerals of the argillic zone comprise smectite, interlayered illite-smectite, kaolinite, zeolite and K-feldspar. Smectitezeolite +/ - interlayered illite-smectite + / $\mathrm{K}$-feldspar form a sub-zone in the relatively shallow part (typically observed in wells $87 \mathrm{~N}$ 17T (Fig. 5d), 89N-22T (Fig. 5e) and 90N-23P), while kaolinite +/- K-feldspar occurs at deeper levels (OAG, unpublished data). Advanced argillic alteration, composed mainly of smectite and mordenite, with minor sericite, kaolinite and alunite (Nitta et al., 1987 and Imai et al., 1988 ) is found locally near the Sarukurazawa fault zone. The surface extent of this argillic to advanced argillic alteration is about $4.4 \mathrm{~km}^{2}$ (Fig. 4; Nitta et al., 1987).

Anhydrite is widespread in the deeper part of the system, where temperatures are greater than 100 to $200^{\circ} \mathrm{C}$. Anhydrite occurs as open-space 


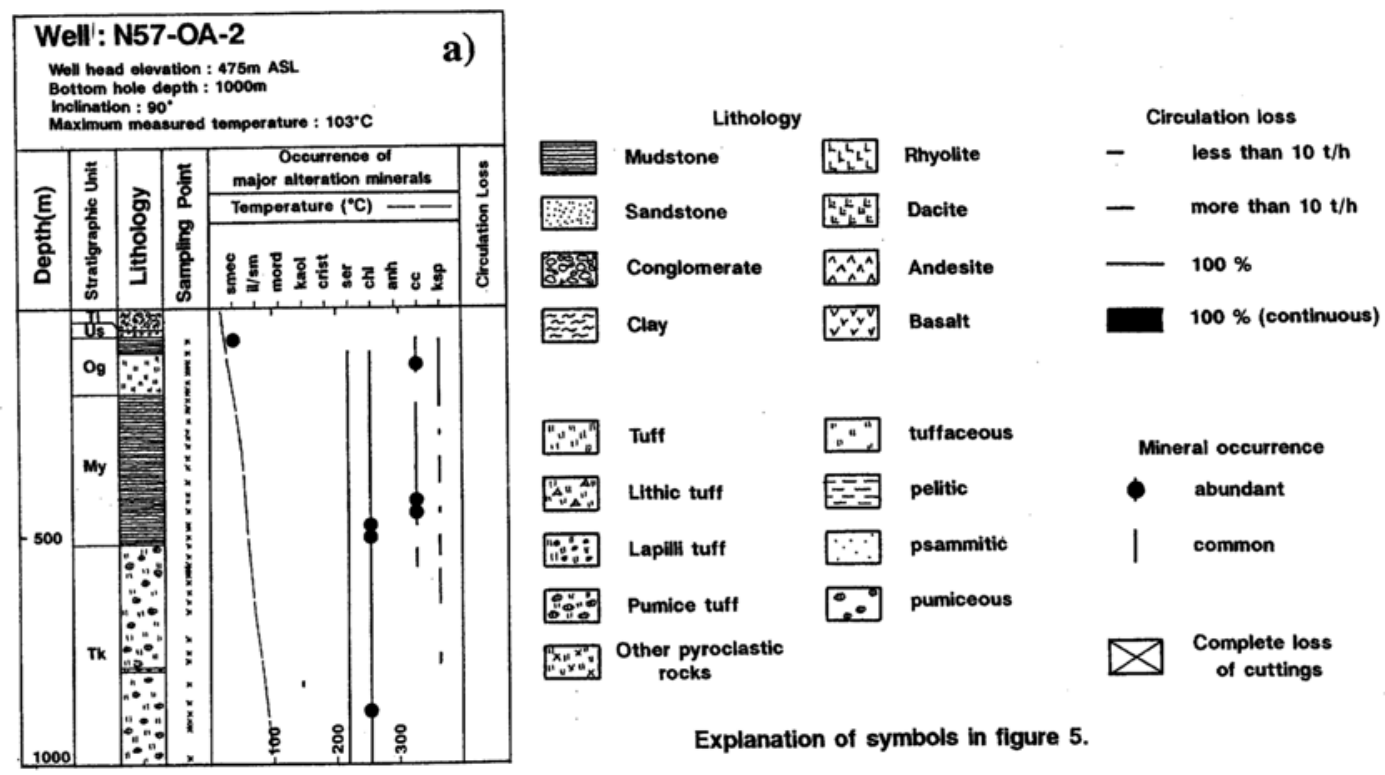

Fig. 5a. Lithology and alteration mineralogy including major circulation-loss points of well OA-2 (compiled from NEDO, 1985). Abbreviations: Sg, Sunagohara formation; Us, Urushikubo formation; Og, Ogino formation; My, Miyashita mudstone member; Tk, Takizawagawa formation; Oh, Oh-hizawa formation; smec, smectite; il/sm, interlayered illite-smectite; mord, mordenite; kaol, kaolinite; crist, cristobalite; ser, sericite; chl, chlorite; anh, anhydrite; $c c$, calcite and ksp, K-feldspar. These abbreviations are the same for the rest of Fig. 5 .

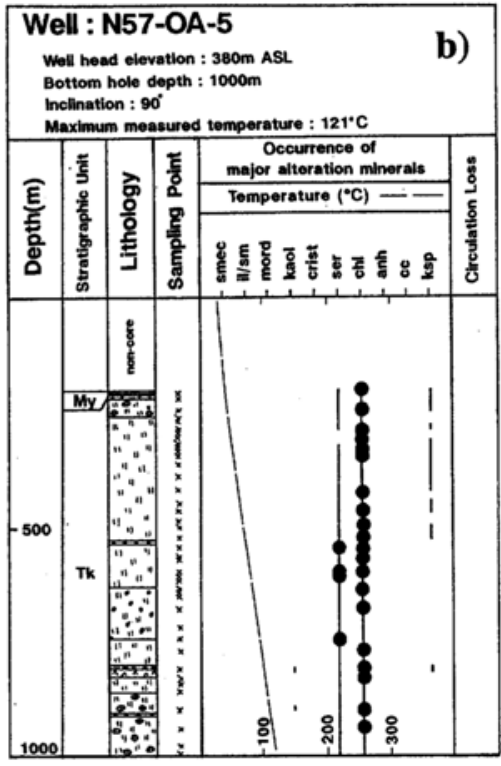

Fig. 5b. Lithology and alteration mineralogy including major circulation-loss points of well OA-5 (compiled from NEDO, 1985).

Fig. 5c. Lithology and alteration mineralogy including major circulation-loss points of well $87 \mathrm{~N}-16 \mathrm{~T}$ (compiled from $O A G$, unpublished data).

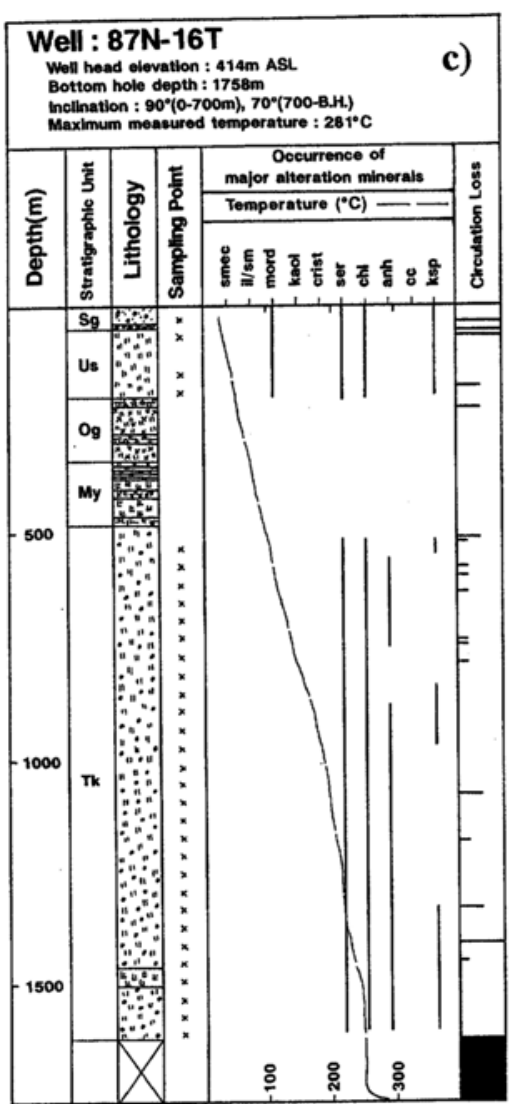




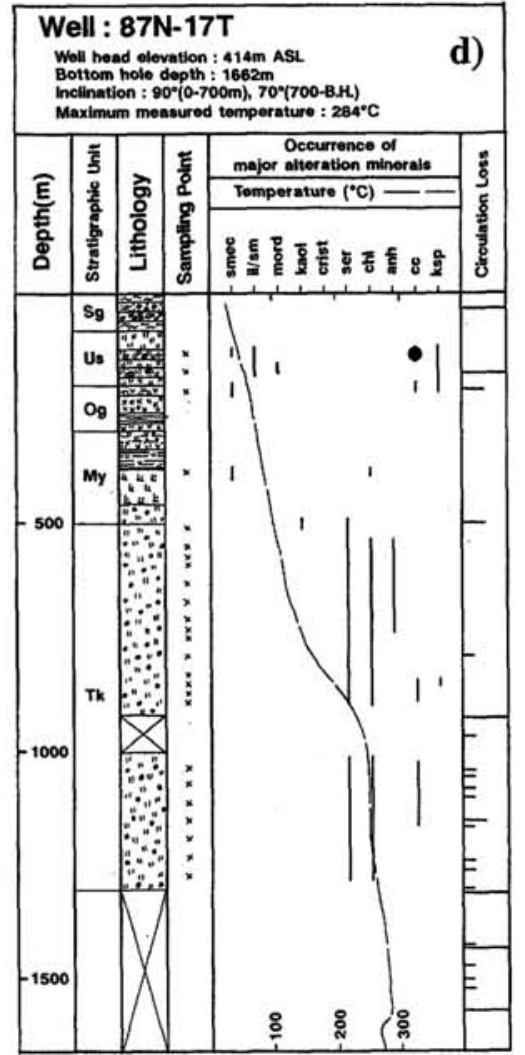

Fig. 5d. Lithology and alteration mineralogy including major circulation-loss points of well $87 \mathrm{~N}-17 \mathrm{~T}$ (compiled from $O A G$, unpublished data).

Fig. 5e. Lithology and alteration mineralogy including major circulation-loss points of well $89 \mathrm{~N}-22 \mathrm{~T}$ (compiled from $O A G$, unpublished data).

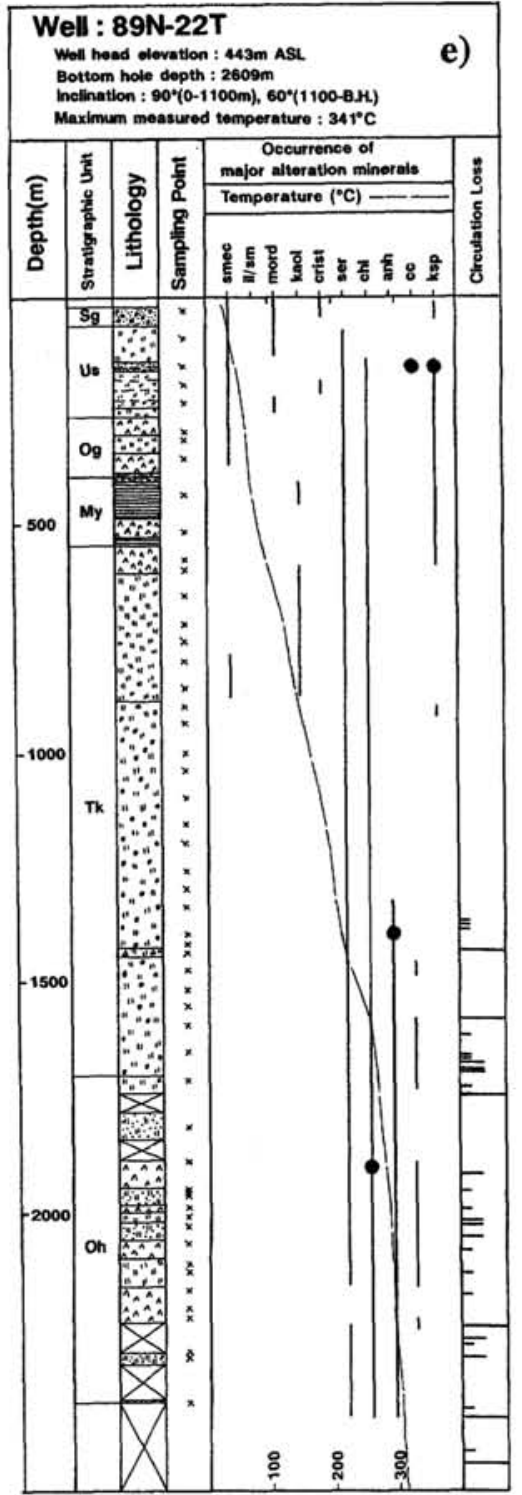

\section{Thermal STRUCTURE}

\section{Direct measurement}

The thermal structure of the geothermal system may be constructed from thermal profiles based on temperatures measured 120 hours after drilling, the time allowed for thermal conditions to stabilize (Fig. 6). The thermal structure is primarily controlled by the fracture system. A zone of argillic alteration at shallow levels appears to act as a barrier to upflow (at depth of 


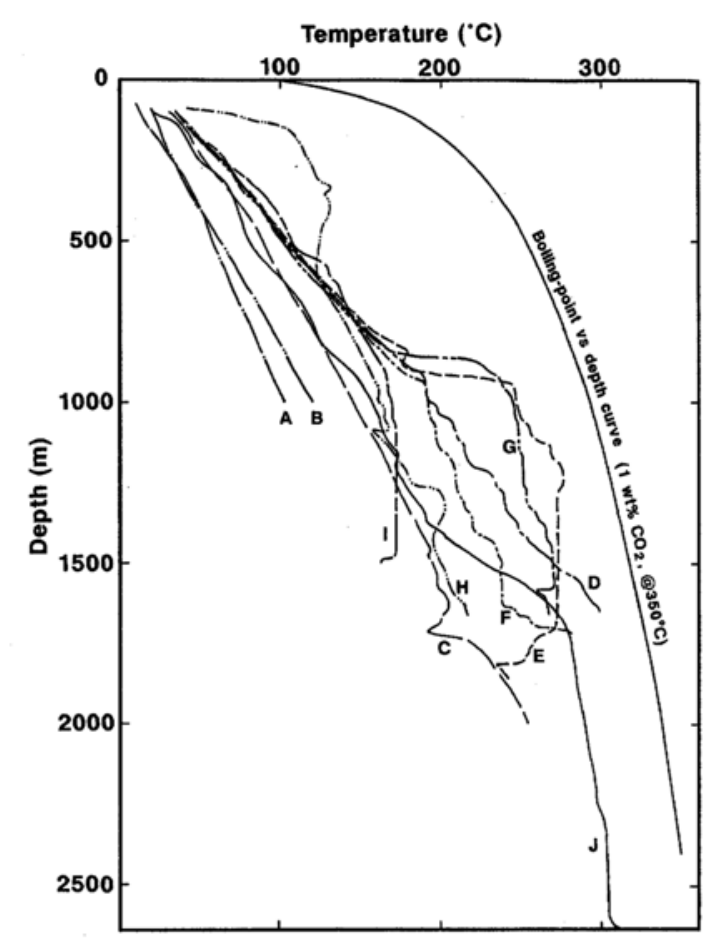

Fig. 6. Initial thermal profiles of several representative wells (after post-drilling stabilization for 120 hours (except 89N-22T, which was $48 \mathrm{~h}$ )) (compiled from NEDO, 1985 and $O A G$, unpublished data). $A b$ breviations: $A, O A-2 ; B, O A-5 ; C, 84 N-1 t ; D, 86 N-$ $11 T$; E, 87N-15T; F, 87N-16T; G, 87N-17T; H, 87N$18 t ; \mathrm{I}, 88 \mathrm{~N}-19 R ; \mathrm{J}, 89 \mathrm{~N}-22 \mathrm{~T}$. The lower levels of wells $11 T, 16 T, 17 T, 18 t, 19 R$ and $22 T$ are inclined. No depth correction for the inclination was made. Maximum difference from the true depth is about $200 \mathrm{~m}$ $(89 \mathrm{~N}-22 T)$. Well head elevations are mainly $400 \pm 50$ $m$ ASL.

$$
\text { about }-200 \mathrm{~m} \text { to }+200 \mathrm{~m} \text { ASL). }
$$

In the deeper part of the system (deeper than $-1000 \mathrm{~m} \mathrm{ASL}$ ), the zone of thermal updoming is located along the Chinoikezawa fault zone, and isotherms open towards the SE. At shallower levels (about $-300 \mathrm{~m}$ to $-1000 \mathrm{~m}$ ASL), the highest temperature isotherms are located between the Chinoikezawa and the Sarukurazawa fault zone. Still closer to the surface (shallower than $-300 \mathrm{~m} \mathrm{ASL}$ ), an axis of thermal maxima changes direction to parallel the Takiyagawa fault zone, trending NE-SW. At a level of $+200 \mathrm{~m} \mathrm{ASL}$, the highest temperature isotherm closes towards the NE, about $2.5 \mathrm{~km}$ from the Chinoikezawa fault zone (Fig. 7; OAG,

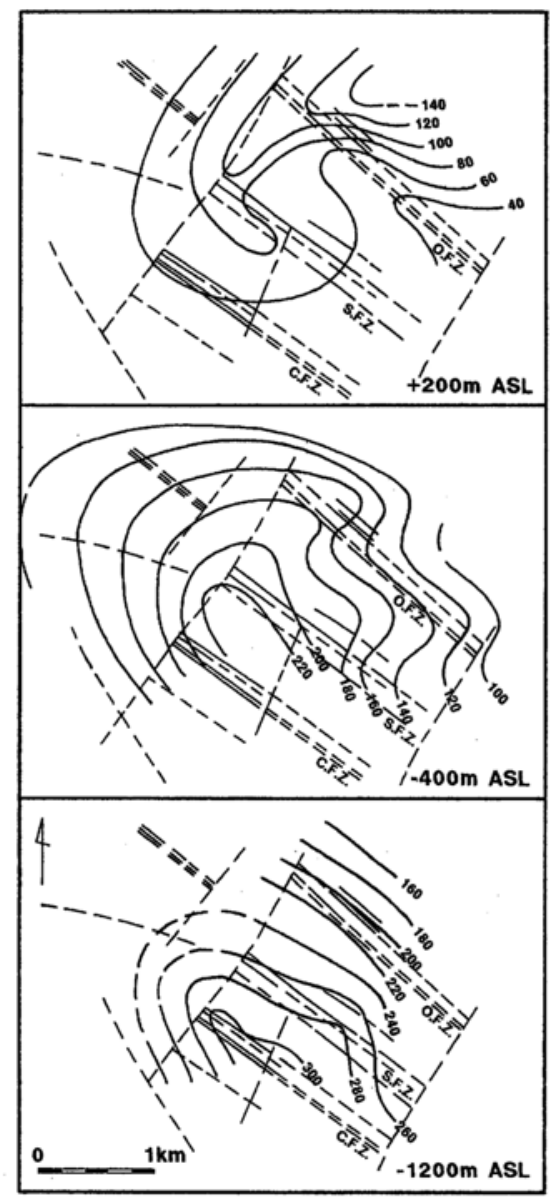

Fig. 7. Temperature distribution at $-1200,-400$ and $+200 \mathrm{~m} \mathrm{ASL}$, with distribution of major fractures at each level (OAG, unpublished data). $A b$ breviations: C.F.Z., Chinoikezawa fault zone; S.F.Z., Sarukurazawa fault zone; O.F.Z., Oizawa fault zone. Symbols: - - , fracture system; - -300 , isotherm with temperature $\left({ }^{\circ} \mathrm{C}\right)$.

unpublished data).

The depth where the high temperature axis changes direction corresponds approximately to the base of the zone of argillic alteration. The temperature gradient increases at that depth (Fig. 8; OAG, unpublished data), which may relate to a convection cell beneath the zone sealed by argillization.

Judging from the thermal profiles, the present system does not appear to be boiling in its natural state, though local zones of boiling in low pressure fractures may exist. 


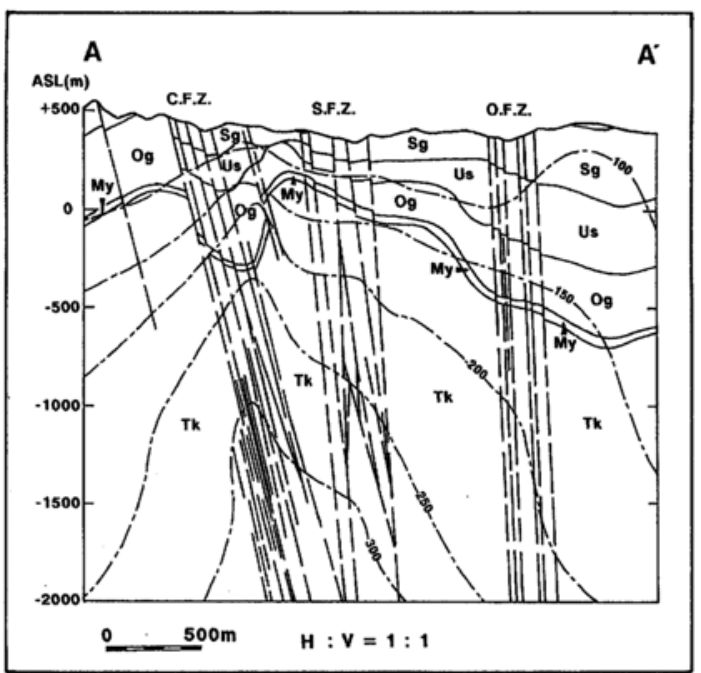

Fig. 8. Temperature cross-section along $A-A^{\prime}$ (Fig. 4), with geology (OAG, unpublished data). Abbreviations are the same as in Figs. 4 and 5. Symbols:

formation boundary; - - fault; -- 300 , isotherm with temperature $\left({ }^{\circ} \mathrm{C}\right)$.

Some wells have thermal inversions at depth (N57-OA-3 and 87N-18t (Fig. 6H)), which probably indicate cool inflows, as in N57-OA-3, where the isotherms pinch with an axis concordant to the Oizawa fault zone (Fig. 7; OAG, unpublished data).

\section{Fluid inclusion thermometry}

Homogenization temperatures of fluid inclusions hosted mainly by anhydrite and calcite have been measured for several wells. All fluid inclusions are two-phase gas and liquid inclusions. No liquid $\mathrm{CO}_{2}$ or halite have been observed. Both primary and secondary inclusions are recognized. The former possess regular shapes and often form clusters (Takenouchi, 1988a).

The degree of filling of the inclusions in the same cluster commonly varies which may indicate boiling during the formation of the mineral (Takenouchi, 1988a).

Homogenization temperatures of most inclusions in anhydrite in OA-7, located between the Sarukurazawa and Oizawa fault zones, appear to agree with the measured down hole temperatures, though some are several tens of degree $\left({ }^{\circ} \mathrm{C}\right)$ higher. Concordance of homogenization

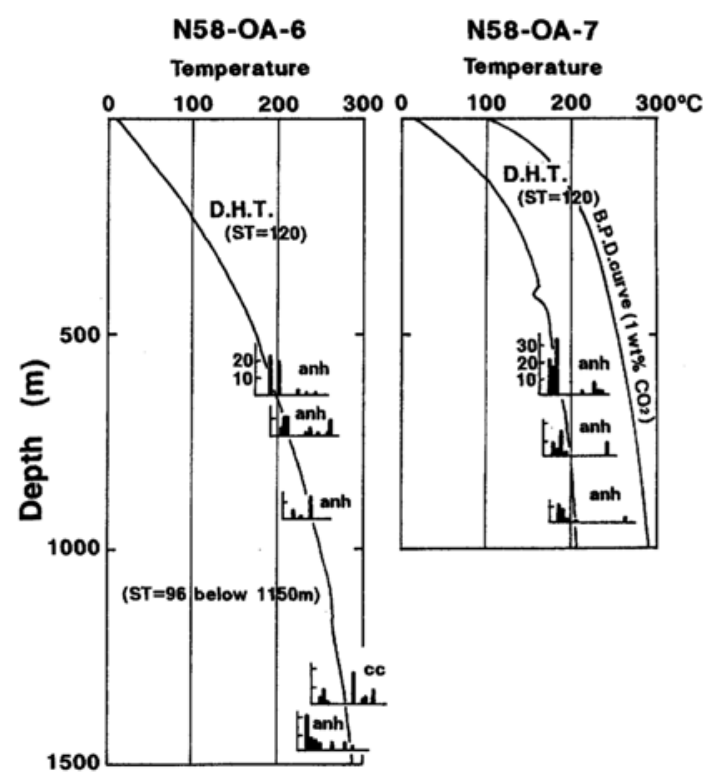

Fig. 9. Distribution of homogenization temperatures of fluid inclusions in anhydrite and calcite including down hole temperature profiles for wells $O A-6$ and OA-7 (Nitta et al., 1987, based on Takenouchi, 1986). Abbreviations: anh, anhydrite; cc, calcite; $S T$, stabilization time after drilling (hours); D.H.T., measured down hole temperature. Boiling-point versus depth curve $\left(1 \mathrm{wt} \% \mathrm{CO}_{2}\right.$ at $\left.350^{\circ} \mathrm{C}\right)$ is also shown for $O A-7$.

temperature with the measured down hole temperature can be observed at levels shallower than $1000 \mathrm{~m}$ depth in OA-6, penetrating the Sarukurazawa fault zone (Fig. 9; Takenouchi, 1985).

Fluid inclusions in sphalerite at GL-1329.5 m of $84 \mathrm{~N}-2 \mathrm{t}$ have homogenization temperature ranging from 196 to $222^{\circ} \mathrm{C}$ (Imai et al., 1988), which is about $50^{\circ} \mathrm{C}$ lower than the present temperature.

\section{Reservoir Conditions Before AND After Expliotation}

\section{Reservoir condition in initial stage}

The reservoir condition at the initial stage of exploration is considered to be very close to that of the natural state. Judging from the following observations made during the initial stage of exploration, the overall Oku-aizu geothermal 


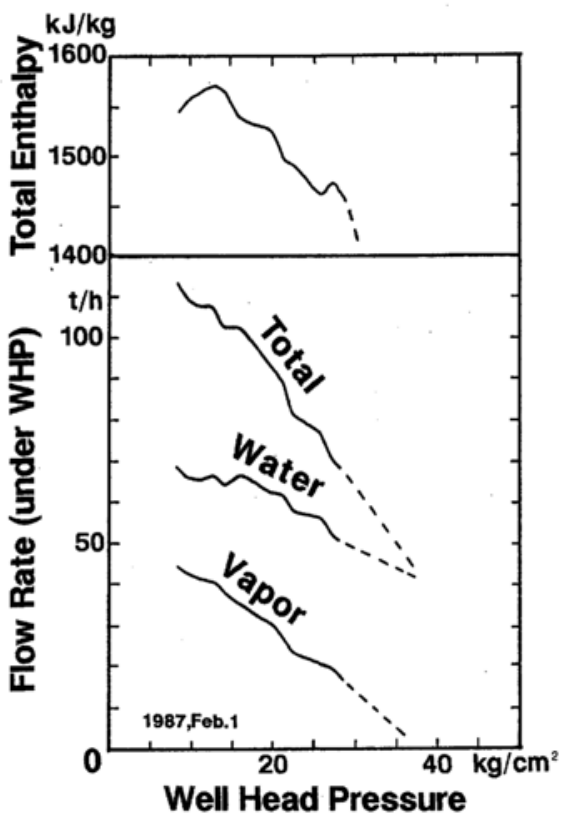

Fig. 10. Total discharge enthalpy versus well head pressure for 85N-6T (Nitta et al., 1987).

system appears to have been sub-boiling, though there may have been minor local zones of boiling.

Some wells drilled in the beginning stage of the exploration (e.g. OA-4, $84 \mathrm{~N}-2 \mathrm{t}$ and $85 \mathrm{~N}-6 \mathrm{~T}$ )
Table 4. Temperature and enthalpy data of geothermal wells

\begin{tabular}{rrrrrrc}
\hline Well & Date & $\begin{array}{c}\text { W.H.P. T.dh } \\
\text { (b.g.) }\end{array}$ & $\begin{array}{c}\text { H.td } \\
\left({ }^{\circ} \mathrm{kJ} / \mathrm{kg}\right)\end{array}$ & $\begin{array}{c}\mathrm{H} .1 \\
(\mathrm{~kJ} / \mathrm{kg})\end{array}$ & $\begin{array}{c}\mathrm{H} . e x \\
(\mathrm{~kJ} / \mathrm{kg})\end{array}$ \\
\hline $0 A-4$ & $84 / 02 / 07$ & 17.5 & 267 & 1140 & 1169 & - \\
$0 \mathrm{~A}-6$ & $83 / 12 / 22$ & 0.7 & 286 & 1603 & 1268 & 335 \\
$84 \mathrm{~N}-1 \mathrm{t}$ & $85 / 06 / 14$ & 1.1 & 254 & 908 & 1105 & - \\
$84 \mathrm{~N}-2 \mathrm{t}$ & $85 / 11 / 08$ & 6.2 & 311 & 1365 & 1407 & - \\
$84 \mathrm{~N}-3 \mathrm{t}$ & $86 / 01 / 16$ & 0.6 & 277 & 1415 & 1220 & 195 \\
$84 \mathrm{~N}-5 \mathrm{t}$ & $84 / 12 / 08$ & 0.0 & 265 & 1220 & 1159 & 61 \\
\hline
\end{tabular}

Original data from Nitta et al. (1987) and NEDO (1985). Abbreviations: W.H.P., well head pressure; T.dh, maximum measured down hole temperature; H.td, total discharge enthalpy; H.l, enthalpy of steam saturated water at T.dh; H.ex, excess enthalpy (H.td-H.l).

had normal enthalpy, while only one (OA-6) showed an excess enthalpy of discharge (Table 4). Most down hole temperature profiles do not reach boiling point for depth temperatures, calculated on the basis of estimated dissolved gas concentrations (Fig. 6). The total discharge enthalpy versus well head pressure for $85 \mathrm{~N}-6 \mathrm{~T}$ (Nitta et al., 1987; Fig. 10) indicates that aquifer boiling takes place around the well due to the pressure drop induced by discharge of the well. The same situation is recognized in other wells. Although local, gas-rich reservoirs were

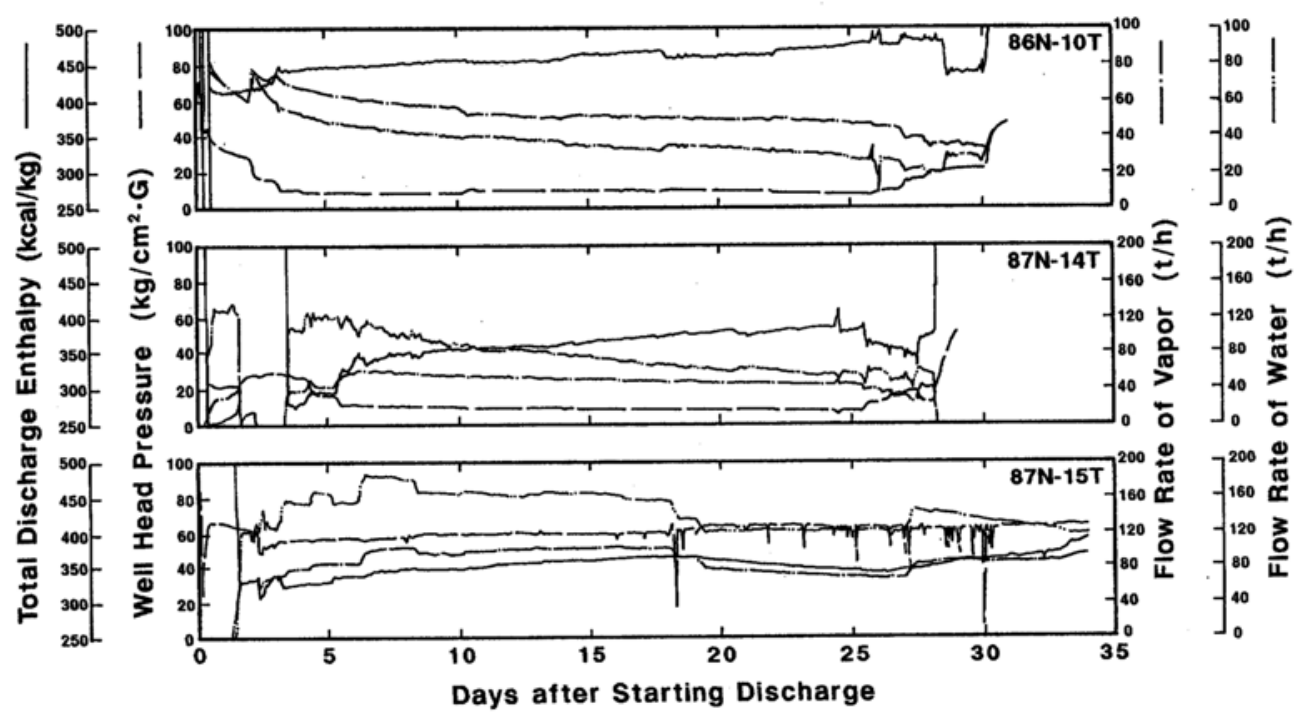

Fig. 11. Total discharge enthalpy changes with time during production tests for several wells (OAG, unpublished data). 
reported (based on drilling records, e.g., -831 $\mathrm{m}$ in 84N-1t; Nitta et al., 1987), these phenomena are considered to be rather exceptional.

\section{Reservoir condition after discharge}

After wells OA-4 and OA-6 discharged geothermal fluid during the first stage of exploration in 1982 and 1983, nine more production wells were drilled up to 1989 and several production tests were carried out. As a result of these discharge tests, the reservoir pressure decreased slightly and discharge-induced reservoir boiling around the geothermal wells subsequently occurred. Most wells showed an excess enthalpy of discharge (Table 4) during their individual production tests.

During the first simultaneous production test of five production wells $(84 \mathrm{~N}-2 \mathrm{t}, 85 \mathrm{~N}-6 \mathrm{~T}, 86 \mathrm{~N}-$ $10 \mathrm{~T}, 87 \mathrm{~N}-14 \mathrm{~T}$ and $87 \mathrm{~N}-15 \mathrm{~T}$, from December, 1987 , to March, 1988), all five wells showed a significant amount of excess enthalpy, up to 600 $\mathrm{kJ} / \mathrm{kg}$. The only exception was well $87 \mathrm{~N}-14 \mathrm{~T}$, which showed normal enthalpy to slight excess enthalpy conditions in the beginning stage of the test. This development of excess enthalpy is considered to be derived from excess steam inflow produced from reservoir boiling caused by the discharge-induced pressure drop. The total discharge enthalpy of each well gradually increased with time during the test (Fig. 11), which indicates extention of boiling around the wells into the reservoir.

Due to the steam generated in an aquifer subjected to extensive amounts of discharge-induced boiling, the composition of the total discharge is seldom representative of the composition of reservoir liquid in the formation, prior to boiling (Seki, 1990b).

\section{Fluid Chemistry}

\section{Chemical characteristics of well discharges}

One characteristic phenomenon of this system is the high gas content in well discharges. The concentrations of non-condensible gases (NCG) in steam separated at about $6.5 \mathrm{~kg} / \mathrm{cm}^{2}$ range from 2 to $10 \mathrm{vol} \%$. Most of the NCG is $\mathrm{CO}_{2}$ (95) to $\left.99 \%\right)$ with the balance being $\mathrm{H}_{2} \mathrm{~S}(0.1$ to $4 \%$ ) and residual gases. Among the residual gases, $\mathrm{N}_{2}$ dominates (78 to $98 \%$ ) (Table 5; NEDO, 1985; Nitta et al., 1987; OAG, unpublished data).

The separated liquid has the highest salinity of geothermal systems in Japan (except for Fushime, which is sea water dominant; Akaku and Yagi, 1988; Akaku, 1990). The dominant anion is $\mathrm{Cl}^{-}(5300$ to $22000 \mathrm{mg} / \mathrm{kg})$ and major cations are $\mathrm{Na}^{+}(2700$ to $10600 \mathrm{mg} / \mathrm{kg})$ with lesser amounts of $\mathrm{K}^{+}(180$ to $2550 \mathrm{mg} / \mathrm{kg})$ and $\mathrm{Ca}^{2+}(26$ to $1750 \mathrm{mg} / \mathrm{kg})$. The silica concentration is also high (440 to $1010 \mathrm{mg} / \mathrm{kg}$ ), reflecting the relatively high reservoir temperature. Remarkably high concentrations of $\mathrm{Mn}^{2+}$ (up to $420 \mathrm{mg} / \mathrm{kg}$ ) is another peculiar characteristic of this system (Table 5; NEDO, 1985; Nitta et al., 1987; OAG, unpublished data).

\section{Estimated reservoir fluid composition prior to boiling}

The composition of the reservoir fluid is necessary in order to calculate mineral-fluid equilibria and to estimate such developmentrelated factors as the potential for scaling. However, as previously mentioned, the reservoir fluid composition cannot be directly determined from total discharge composition for wells with excess enthalpy. This is because the excess steam will have a higher and probably variable gas concentration compared with the original aquifer fluid prior to boiling, due to fractionation under different conditions of boiling (Henley, 1984). Therefore, to estimate the reservoir fluid composition prior to boiling, the steam fraction and concentration of each component in steam at the feed point(s) has to be estimated.

Based on this concept and integrated with an aquifer boiling model, the reservoir fluid composition prior to boiling for wells $85 \mathrm{~N}-6 \mathrm{~T}, 87 \mathrm{~N}$ $14 \mathrm{~T}$ and $87 \mathrm{~N}-15 \mathrm{~T}$ was estimated (Seki, 1990b). The calculated concentrations of non-volatile components for the three wells producing from the same fracture zone (Chinoikezawa fault zone), agreed well with each other. The esti- 


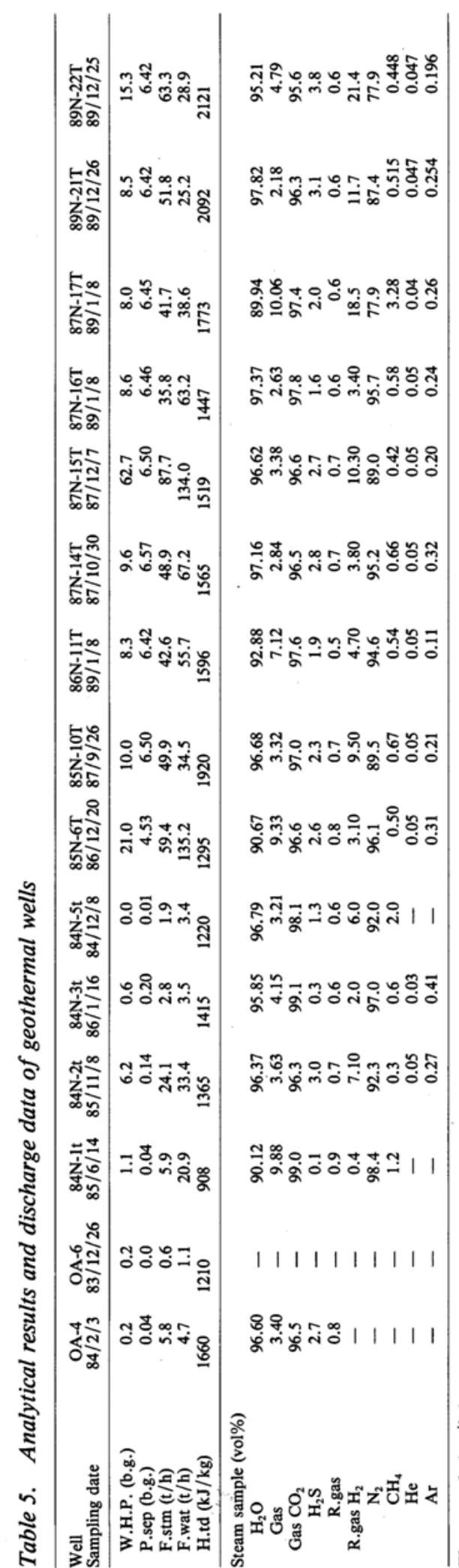

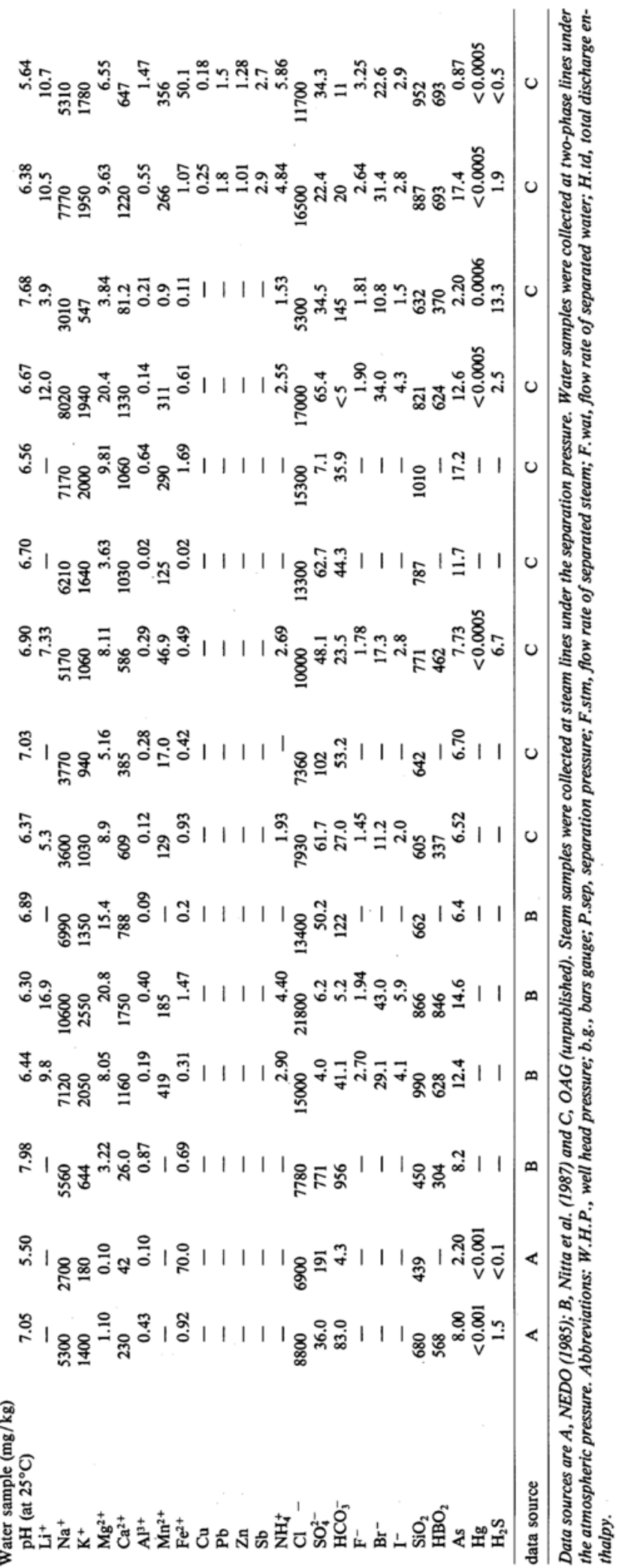




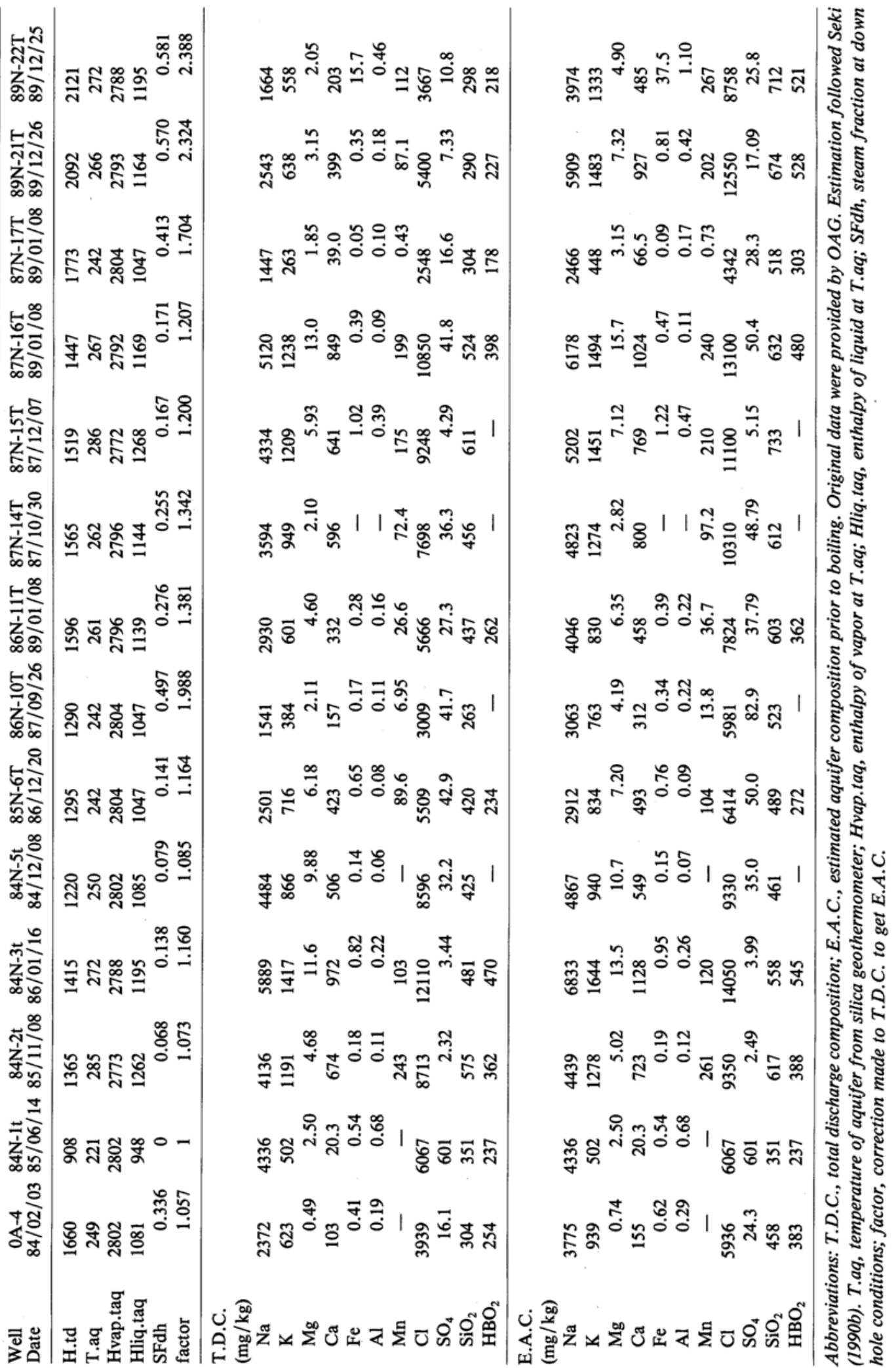




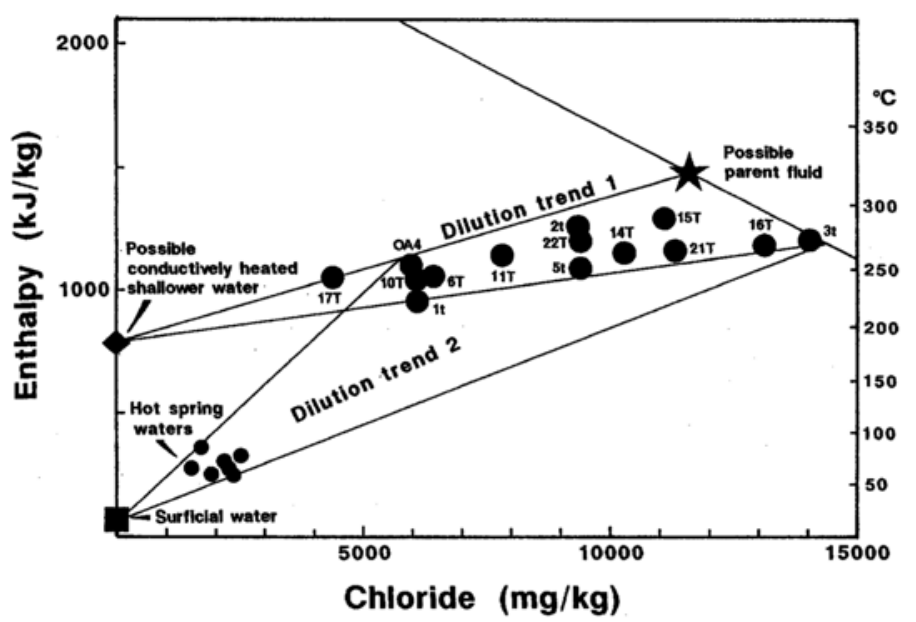

Fig. 12. Chloride-enthalpy diagram for calculated reservoir fluids. Original data provided by OAG. Calculation of reservoir compositions based on results by Seki (1990b).

mated ranges of gas concentrations in the reservoir liquid prior to boiling are 0.3 to $1.0 \mathrm{wt} \%$ for $\mathrm{CO}_{2}$ and 150 to $250 \mathrm{mg} / \mathrm{kg}$ for $\mathrm{H}_{2} \mathrm{~S}$, with the upper values most likely (Seki, 1990b).

The estimated concentrations of non-volatile components in the reservoir liquid prior to boiling, based on the analytical results listed in Table 5 and corrected for steam loss, are listed in Table 6.

The fluid $\mathrm{pH}$ at reservoir temperature is calculated from the estimated reservoir fluid composition using the chemical speciation code "PECS" (Takeno, 1988), and ranges from 4.1 to 5.5 (Seki, unpublished). These values are somewhat higher than the $\mathrm{pH}$ of 3.79 calculated assuming no excess steam and consequently no excess $\mathrm{CO}_{2}$ in the total discharge (Ichikuni and Tsurumi, 1988).

\section{Probable fluid types and mixing trends}

A chloride-enthalpy plot of initial discharge compositions of each production well, corrected to reservoir values, is shown in Fig. 12. Well $87 \mathrm{~N}-15 \mathrm{~T}$ appears to be closest in composition to a "parent fluid", given its high chloride concentration and the highest temperature indicated by the silica geothermometer (Fournier and Potter, 1982).

It is difficult to confidently determine the degree of boiling, and dilution trends, because of the large excess enthalpies, though some possibilities may be considered. The first is a recognition of a mixing trend between the deep fluid (of high salinity and higher enthalpy, represented by $87 \mathrm{~N}-15 \mathrm{~T}$ ) and a shallower, possibly conductively (or steam) heated ground water of zero salinity and a temperature less than $200^{\circ} \mathrm{C}$. This cannot be proven because down hole samples of marginal monitor and exploration wells are not available.

The second probable trend is that of mixing of deeper fluid or mixed fluid of the first trend with cold ground water at relatively shallow depths. This mixing is responsible for the waters discharging from hot springs along the Takiyagawa fault zone, which have approximately 1500 to $2500 \mathrm{mg} / \mathrm{kg}$ chloride and temperatures of 61 to $93^{\circ} \mathrm{C}$ (Table 3).

\section{Isotopic characteristics and component ratios}

An oxygen and hydrogen isotopic study of geothermal waters was conducted Dr. O. Matsubaya and presented in Nitta et al. (1987) (Fig. 13). Isotopic values of meteoric waters collected in this area lie on the local meteoric water line ( $\delta^{18} \mathrm{O}:-10$ to -12 per mil, $\delta \mathrm{D}:-66$ to -72 per mil), described by Sakai and Matsubaya (1974). Geothermal fluids discharging from wells have 


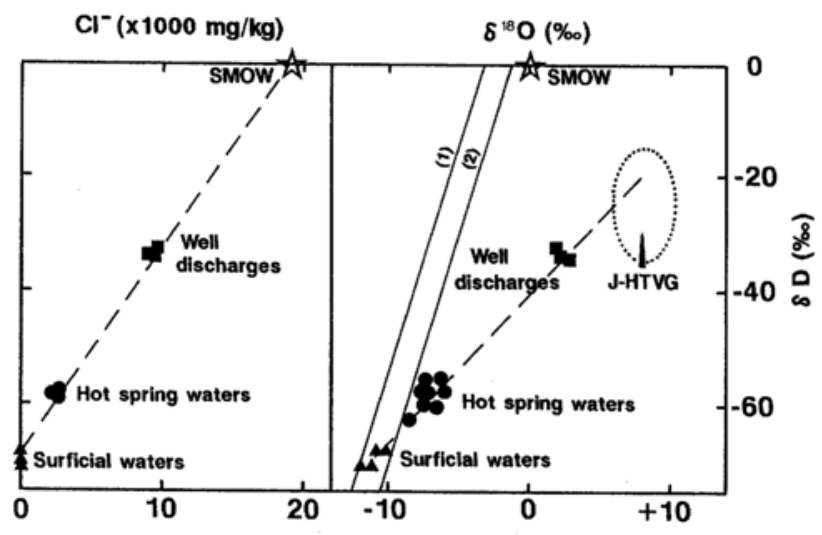

(a)

(b)

Fig. 13. (a) $\delta^{18} \mathrm{O}$-chloride diagram for geothermal well discharges, hot spring waters and local meteoric waters (modified from Nitta et al., 1987). (b) $\delta^{18} O-\delta \mathrm{D}$ diagram for geothermal well discharges, hot spring waters and local meteoric waters. The compositional range of Japanese high temperature volcanic gas (J-HTVG) is also shown (modified from Nitta et al., 1987). Symbols: $\boldsymbol{\bullet}$, geothermal well discharge; $\bullet$, hot spring water; $\boldsymbol{\Delta}$, local meteoric water. Line (1) $\left(\delta D=8 \delta^{18} \mathrm{O}+26\right)$ and (2) $\left(\delta D=8 \delta^{18} \mathrm{O}+10\right)$ are local meteoric water lines according to Sakai and Matsubaya (1974).

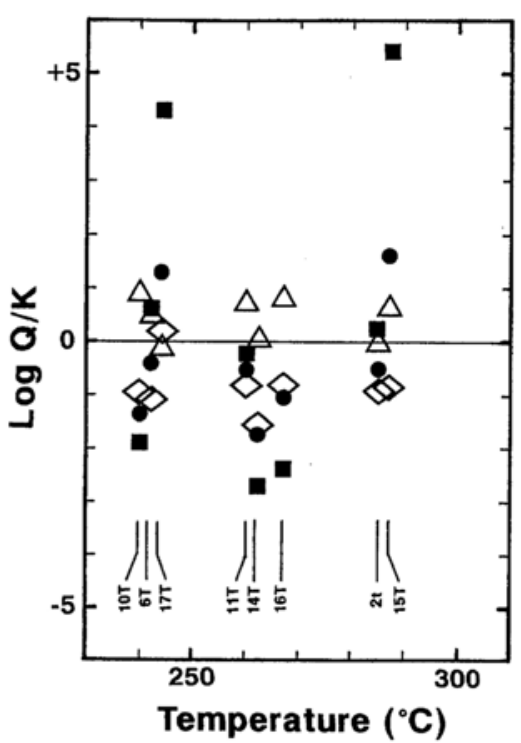

Fig. 14. Reservoir temperature versus saturation indices $(\log Q / K)$ for calcite, anhydrite, $K$-feldspar and $K$-mica based on the estimated composition of reservoir fluid (Seki, unpublished data). Original data provided by OAG. Estimation based on gas results of Seki (1990b), with saturation calculations carried out by PECS (Takeno, 1988). Reservoir temperatures were determined by Fournier and Potter (1982). Gas concentrations were assumed to be 1 wt $\%$ for $\mathrm{CO}_{2}$ and $250 \mathrm{mg} / \mathrm{kg}$ for $\mathrm{H}_{2} \mathrm{~S}$ for all wells. Symbols: muscovite; $\bullet, K$-feldspar; $\triangle$, anhydrite; $\diamond$, calcite. much heavier values of oxygen $\delta^{18} \mathrm{O}:+2$ to +3 per mil) and hydrogen ( $\delta \mathrm{D}:-32$ to -35 per mil). The isotopic values of hot spring waters lie on a line connecting these two endmembers, indicating that the hot springs are produced by mixing of deep geothermal fluid and local ground water, as suggested from chloride-enthalpy relations (Fig. 12). This mixing trend is also clear on the chloride- $\delta^{18} \mathrm{O}$ diagram. According to Nitta et al. (1987), Matsubaya believes that the geothermal fluids are formation waters related to Miocene sea water trapped in formations, since the geothermal fluids lie on a line connecting local ground waters and sea water on the chloride- $\delta^{18} \mathrm{O}$ diagram (Fig. 13).

However, the isotopic composition of geothermal fluids are consistent with local meteoric water dilution of a fluid with composition similar to typical Japanese high temperature volcanic gases, the latter having values of +6 to +10 per mil for $\delta^{18} \mathrm{O}$ and of -15 to -35 per mil for $\delta \mathrm{D}$ (Matsuo et al., 1974; Mizutani et al., 1986). This correlation suggests a significant contribution of magmatic fluids to this geothermal system, with acidity neutralized at depth. The same relationship for chloride- $\delta \mathrm{D}$ and $\delta^{18} \mathrm{O}-\delta \mathrm{D}$ 
is noted for the Nigorikawa geothermal system (Yoshida, 1991), who argues for a sea water component.

The uncertainty of the fossil sea water hypothesis is indicated by the $\mathrm{B} / \mathrm{Cl}$ and $\mathrm{Br} / \mathrm{Cl}$ ratios. The $\mathrm{B} / \mathrm{Cl}$ weight ratio of separated water from geothermal wells ranges from 0.006 to 0.021 (Nitta et al., 1987; OAG, unpublished data, Table 5), much higher than that of sea water $(0.00024)$. Also, the $\mathrm{Br} / \mathrm{Cl}$ weight ratio is 0.0014 to 0.0020 , versus 0.0034 of sea water.

\section{Mineral-fluid saturation conditions}

Saturation conditions of several minerals for the estimated reservoir fluid have been calculated. The estimated reservoir fluids (corrected for excess enthalpy sampling) of both $87 \mathrm{~N}-14 \mathrm{~T}$ and $87 \mathrm{~N}-15 \mathrm{~T}$ are undersaturated with respect to calcite $(\log \mathrm{Q} / \mathrm{K}:-1.55$ and -0.80$)$, are saturated to oversaturated with anhydrite $(+0.03$ and +0.58$)$, and are oversaturated with pyrite $(+1.98$ and +2.92$)$ (Seki, 1990a), based on calculation using the chemical speciation code "PECS" (Takeno, 1988). Similar results were also obtained for other wells in the system (Fig. 14). Undersaturation of calcite is also indicated by the fact that all wells except $86 \mathrm{~N}-10 \mathrm{~T}$ are free of calcite scaling (Nitta et al., 1987).

The saturation index for $\mathrm{K}$-feldspar varies from -1.7 to +1.6 , and that for $\mathrm{K}$-mica ranges widely from -2.8 to +5.4 (Fig. 14).

\section{Fluid inclusion chemistry}

The gas composition of fluid inclusions in anhydrite from $84 \mathrm{~N}-2 \mathrm{t}, 86 \mathrm{~N}-13 \mathrm{t}$ and $87 \mathrm{~N}-18 \mathrm{t}$ were determined by crushing and chromatographic analysis (Takenouchi, 1988a and 1988b). The ranges of mole fractions of gases analyzed were $\mathrm{CO}_{2}: 0.87-0.95, \mathrm{~N}_{2}: 0.01-$ 0.11 and $\mathrm{CH}_{4}: 0.01-0.04$ (mole fraction), which basically agrees with the composition of the present fluids. The net $\mathrm{CO}_{2}$ concentration in the inclusion liquid varies from 5.2 to $6.8 \mathrm{wt} \%$, somewhat higher than that estimated here (about 1.0 wt\%).

\section{Base Metal Mineralization}

Sulfide mineralization occurs as mainly veinlets in drill core, and consists of pyrite $+/-$ sphalerite $+/$ - galena $+/-$ chalcopyrite from wells such as OA-4, OA-6, $84 \mathrm{~N}-2 \mathrm{t}$ and $87 \mathrm{~N}-15 \mathrm{~T}$ (Table 7; NEDO, 1985; Nitta et al., 1987; OAG, unpublished data). From drill cuttings of produc-

Table 7. Distribution of base metal sulfides in drilling cores and cuttings of geothermal wells (compiled from NEDO, 1985 and OAG, unpublished data). All data are elevations in m ASL.

\begin{tabular}{|c|c|c|c|}
\hline Well & Sphalerite & Galena & Chalcopyrite \\
\hline N57-OA-2 & -41 & & $-41,-120,-412$ \\
\hline N57-OA-3 & & -944 & \\
\hline N57-OA-4 & $\begin{array}{c}+65,-7,-21 \\
-83 \text { to }-260\end{array}$ & $\begin{array}{c}-21 \\
-83 \text { to }-260\end{array}$ & $\begin{array}{c}+65 \\
-83 \text { to }-260\end{array}$ \\
\hline N58-OA-5 & & -381 & \\
\hline N58-OA-6 & $-656,-678,-1098$ & & \\
\hline N58-OA-7 & $-563,-570,-589$ & -570 & -570 \\
\hline $84 \mathrm{~N}-2 \mathrm{t}$ & $\begin{array}{c}-687 \text { to }-764 \\
-807,-873\end{array}$ & $\begin{array}{c}-687 \text { to }-764 \\
-873\end{array}$ & -807 \\
\hline $84 \mathrm{~N}-4 \mathrm{r}$ & +239 & +239 & +275 to +239 \\
\hline $84 \mathrm{~N}-5 \mathrm{t}$ & $-744,-981$ & -744 & \\
\hline $85 \mathrm{~N}-6 \mathrm{~T}$ & +288 to +268 & & \\
\hline \multirow[t]{3}{*}{$87 \mathrm{~N}-14 \mathrm{~T}$} & +252 to +132 & & \\
\hline & -88 to -108 & & \\
\hline & -386 to -504 & & \\
\hline \multirow[t]{3}{*}{$87 \mathrm{~N}-15 \mathrm{~T}$} & +280 to +200 & -1457 & \\
\hline & +140 to +100 & & \\
\hline & -1457 & & \\
\hline
\end{tabular}


tion wells $87 \mathrm{~N}-14 \mathrm{~T}$ and $87 \mathrm{~N}-15 \mathrm{~T}$, sphalerite and pyrite have been recognized by XRD (OAG, unpublished data). These sulfide minerals often have euhedral crystals coexisting with euhedral quartz +/ - anhydrite +/ - rhodochrosite, and are on the surface of the open-space fractures in production zones (Nitta et al., 1987). In addition, the base metals in solution were found to be relatively high in separated waters from well discharges (e.g., $89 \mathrm{~N}-21 \mathrm{~T}$ and $89 \mathrm{~N}-22 \mathrm{~T}$; Table 5). Therefore, this sulfide mineralization is considered to be the product of the current geothermal system (Imai et al., 1988).

\section{Precious Metal-bearing Sulfide Scaling}

Sulfide scales are found on the inside casing wall of well $84 \mathrm{~N}-2 \mathrm{t}$, and inside the two-phase line of surface facilities at $87 \mathrm{~N}-15 \mathrm{~T}$. The latter includes a significant amount of precious metals.

Minerals found in scale taken from the casing wall, from the $980 \mathrm{~m}$ depth to the well head of $84 \mathrm{~N}-2 \mathrm{t}$, are pyrrhotite, pyrite, alabandite, wurtzite (Mn-bearing), sphalerite (Mn-bearing), galena, cubanite, chalcopyrite, tetrahedrite, pyrargyrite, stibarsen, calcite and rhodochrosite (Imai et al., 1987 and 1988). This well cuts the Chinoikezawa fault zone below about $1000 \mathrm{~m}$ depth. Measured temperature and pressure ranges for this section of well were 165 to $305^{\circ} \mathrm{C}$ and 7 to $117 \mathrm{~kg} / \mathrm{cm}^{2}$, respectively (Imai et al., 1987 and 1988).

Sulfide scales precipitated in the two-phase line down stream of the well head pressure control valve of $87 \mathrm{~N}-15 \mathrm{~T}$ during a 141 day discharge test from November, 1987, to March, 1988. Total weight of the sulfide scales precipitated in the section was about $433 \mathrm{~kg}$ (Nitta et al., 1991). Sulfide minerals of $\mathrm{Au}, \mathrm{Ag}, \mathrm{Cu}, \mathrm{Pb}$ and $\mathrm{Zn}$ are concentrated just after the well head control valve, where a large pressure and temperature drop rapidly occurs (about $100^{\circ} \mathrm{C}$ and 50 $\mathrm{kg} / \mathrm{cm}^{2}$ decrease). The major mineral is tetrahedrite with fine grained galena. Sphalerite is also present, with a vesicular to compact texture (Abe et al., 1990). The gold and silver con-

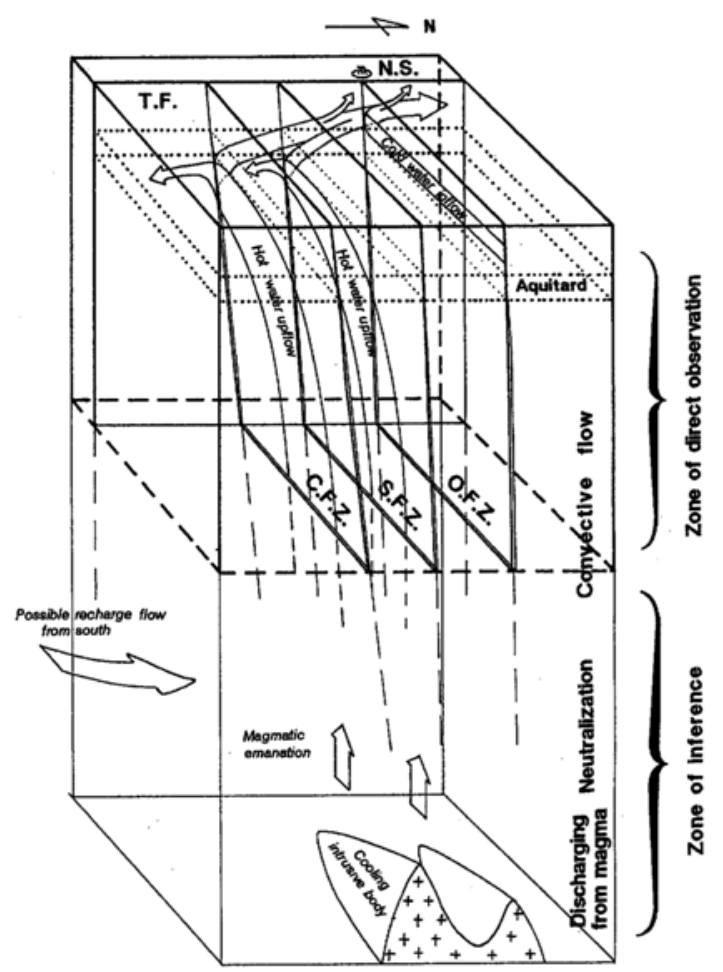

Fig. 15. Structural and fluid flow model of the Okuaizu geothermal system. Abbreviations are the same as in Fig. 4.

centration ranges from 1.2 to $116 \mathrm{mg} / \mathrm{kg}$ and 0.04 to $3.49 \mathrm{wt} \%$, respectively (Nitta et al., 1991). The scales also have $\mathrm{Cu}, \mathrm{Pb}$ and $\mathrm{Zn}$ maxima of $16.0 \mathrm{wt} \%, 15.0 \mathrm{wt} \%$ and $15.4 \mathrm{wt} \%$, respectively (Nitta et al., 1991; Aoki, 1989).

\section{Flow Model of The System}

By integrating the geological, thermal, structural, hydrological and geochemical information described above, the following model has been deduced for the overall structure of the pre-exploited geothermal system at Oku-aizu (Fig. 15).

The heat source probably exists under the SE extension of the Chinoikezawa fault zone, judging from the isotherm distribution at deeper levels (for example, $-1200 \mathrm{~m}$ ASL; Fig. 7). This heat source is most likely a cooling silicic igneous body, perhaps related to the Yunotake rhyolites ( 0.2 to $0.5 \mathrm{Ma}$; Table 2) or the Numazawa volcano which is located about $10 \mathrm{~km}$ west of the 
system and was active about 5000 years ago.

Underground fluid flow in the Oku-aizu system is strongly controlled by the fracture system accompanying the fault zones. The permeability of the bedrock (Takizawagawa Formation) in the production zone is generally quite low. Geothermal fluid rises along the deeper portion of the Chinoikezawa and probably Sarukurazawa fault zones, both of which are steeply dipping NE and striking NW. The zone of argillic alteration and the Miyashita mudstone member from about $-800 \mathrm{~m}$ to $+200 \mathrm{~m}$ ASL act as aquitards where open-space fractures are not connected. Consequently, the high temperature geothermal fluid which is ascending below the sealed zone does not easily discharge to shallow levels.

A portion of the convecting geothermal fluid discharges along the Takiyagawa fault, which strikes NE and dips steeply SE. This fault intersects the Chinoikezawa and Sarukurazawa fault zones at their NW ends. The outflow rises to the NE along the Takiyagawa fault, and is finally mixed with cold ground water near the surface. Some of the flow encounters a cold influx along the Oizawa fault zone near the intersection of the two fault systems. The Nishiyama hot springs (elevation: $290 \mathrm{~m} \mathrm{ASL}$ ) are discharges of these mixed fluids.

Underground fluid generally flows from south to north. Therefore, the expected recharge of the system may be to the south, an area of topographic high extending from Mt. Sarukuragatake (peak elevation: 907 m ASL; Fig. 2).

The reservoir was not boiling in its natural state, except for local upflow in some fractures. However, the fluid is presently boiling around the geothermal wells due to the discharge-induced pressure decrease.

The most conspicuous chemical characteristics of the geothermal system is the high salinity and large concentration of gases (dominantly $\mathrm{CO}_{2}$ ). These characteristics, in conjunction with the trends in isotopic composition, suggest a significant contribution of magmatic fluid to the system. This may also acount for the very high temperatures (maximum measured temperature of $341^{\circ} \mathrm{C}$ at $-2610 \mathrm{~m}$ of $89 \mathrm{~N}-22 \mathrm{~T}$; OAG, unpublished data) in the deeper portion of the system. If true, then the acidic magmatic component has been neutralized before ascending to the drilled portion of the system.

\section{Conclusions}

The physical and chemical characteristics and a model of the Oku-aizu geothermal system are summarized as follows.

Geothermal fluid flow in the Oku-aizu geothermal system is strongly controlled by a fracture system. There are three major fracture zones called the Chinoikezawa, the Sarukurazawa and the Oizawa fault zones, striking NW and dipping steeply NE. The former two produce high enthalpy geothermal discharges.

A high temperature fluid convects upward until it is limited by a sealed zone composed of argillic alteration products such as smectite, interlayered illite-smectite and kaolinite. The Miyashita mudstone member, located approximately at the same elevation as the argillic alteration, also acts as an aquitard.

The system had little boiling in its natural state, judging from well discharges and measured temperature profiles during the initial stage of exploration. However, the reservoir is now boiling around geothermal wells due to the pressure drop caused by discharging of geothermal fluid. Consequently, all producing geothermal wells presently have excess enthalpy.

The deeper reservoir fluid has a high temperature (greater than $300^{\circ} \mathrm{C}$ ), and is estimated to have a salinity of about $2 \mathrm{wt} \%$ and a large gas component (about $1 \mathrm{wt} \% \mathrm{CO}_{2}$ and $250 \mathrm{mg} / \mathrm{kg}$ $\left.\mathrm{H}_{2} \mathrm{~S}\right)$.

The chemical characteristics of high salinity and gas contents are considered to be related to a magmatic component in the discharge. Isotopic characteristics and very high measured temperature $\left(341^{\circ} \mathrm{C}\right)$, much higher than most geothermal systems in Japan, also support this idea.

Sulfide mineralization, such as pyrite, sphalerite, chalcopyrite and galena observed in 
drill cores, appear to be related to the present geothermal fluid, judging from their mode of occurrence, high concentrations of base metals in solution, and the fact that similar sulfide is depositing in several geothermal wells in this system. Recently reported $\mathrm{Au}$ - and Ag-bearing sulfide scaling in two-phase lines in surface facilities indicates that the system is also transporting $\mathrm{Au}$ and $\mathrm{Ag}$.

To improve our understanding of the evolution of the system, a detailed description of vein systems reflecting each stage of alteration are necessary, in particular focusing on overprinted alteration assemblages. Also, further study on the composition of the geothermal fluid and on water-rock interaction will help to confirm the proposed magmatic component to the system and understand its neutralization. Additional lithologic, volcanologic and structural studies will also contribute to the understanding of the volcano-tectonic evolution of this area, necessary to place the present hydrothermal system in a context of magmatic activity.

Acknowledgments-I wish to express thanks to Okuaizu Geothermal Co., Ltd. for permission to use much unpublished data, without which this review could not have been accomplished. Fruitful discussions with Mr. M. Adachi and Mr. Y. Abe, and cooperative work with Mr. K. Inoue, Mr. K. Seo, Mr. F. Hibi and Mr. K. Saiki, are gratefully acknowledged. Helpful suggestions and critical reading of the original manuscript by Dr. J. W. Hedenquist and Dr. G. O. Fridleifsson are appreciated. I also appreciate the encouragement from Dr. Y. Mastuhisa and Dr. J. W. Hedenquist for completing this review, and continuous collaborative work and helpful suggestions from Dr. M. Aoki.

\section{REFERENCES}

Abe, Y., Inoue, K., Takahashi, M., Adachi, M. and Nitta, T. (1990) Heavy metal precipitation from geothermal fluid of $87 \mathrm{~N}-15 \mathrm{~T}$ production well in Okuaizu field. Mining Geol. 40, 43 (in Japanese).

Akaku, K. (1990) Geochemical study on mineral precipitation from geothermal waters at the Fushime field, Kyushu, Japan. Geothermics 19, 455-467.

Akaku, K. and Yagi, M. (1988) Mineral precipitation from the saline geothermal water from the Fushime area, Kyushu, Japan: The precipitation process of anhydrite. Proc. 10th New Zealand Geothermal Workshop, 229-234.

Aoki, M. (1989) Heavy metal concentration in pipeline scale from 15T (preliminary results). unpublished Geol. Surv. Japan internal rep.

Chiba, H. (1990) Chemistry of Japanese geothermal waters. Abst. Annual meeting Geochem. Soc. Japan, 254 (in Japanese).

Fournier, R. O. and Potter, R. W. (1982) A revised and expanded silica (quartz) geothermometer. Geotherm. Resour. Counc. Bull. 11, 3-12.

Hayakawa, N., Suzuki, S. and Oda, S. (1977) Diagenesis and hydrothermal alteration of the Neogene rocks in the Aizu district, Japan. Mining Geol. 27, 367-378 (in Japanese).

Henley, R. W. (1984) Aquifer boiling and excess enthalpy wells. Rev. Econ. Geol. 1, 143-153.

Hirukawa, T., Ando, N. and Sumi, K. eds. (1981) Chemical composition of the thermal waters from fifteen main Japanese geothermal fields. Geol. Surv. Japan. Rept. 262, 403p (in Japanese).

Ichikuni, M. and Tsurumi, M. (1988) pH calculation for geothermal fluids at reservoir temperature. Mining Geol. 38, 302-304.

Imai, H., Adachi, M., Takahashi, M., Yamaguchi, M. and Yashiro, K. (1987) Sulfide minerals from the test well in the Okuaizu geothermal area, Fukushima prefecture. Mining Geol. 37, 69 (in Japanese).

Imai, H., Adachi, M., Takahashi, M., Yamaguchi, M. and Yashiro, K. (1988) Sulfide mineralization in Oku-aizu geothermal field, with the genetical relation to the epithermal gold deposits. Mining Geol. 38, 291-301 (in Japanese).

Ishihara, Y. (1988) The regional report on survey to identify and promote geothermal development; Oku-aizu area. Geotherm. Ener. 13, 9-36 (in Japanese).

Kato, H., Awata, Y. and Shimokawa, K. (1984) Geol. Surv. Japan 1:500,000 Neo-tectonic map sheet 7, Niigata.

Komuro, H. (1978) The formation of the late Miocene collapse basin at the Yanaizu district, Fukushima prefecture, Japan. Earth Science (Chikyu Kagaku) 32, 68-83 (in Japanese).

Matsuo, S., Suzuki, T., Kusakabe, M., Wada, H. and Suzuki, M. (1974) Isotopic and chemical compositions of volcanic gases from Satsuma-Iwojima, Japan. Geochem. J. 8, 165-173.

Ministry of International Trade and Industry (Geol. Surv. Japan) (1978) Fundamental Investigation Report for Geothermal Development, No. 5, Nishiyama dist. (I), (in Japanese). 
Mizutani, T., Hayashi, S. and Sugiura, T. (1986) Chemical and isotopic compositions of fumarolic gases from Kuju-Iwoyama, Kyushu, Japan. Geochem. J. 20, 273-285.

New Energy Development Organization (1985) Geothermal development research report, no. 8, Oku-aizu region, 811p (in Japanese).

Nitta, T., Adachi, M., Takahashi, M., Inoue, K. and Abe, Y. (1991) Heavy metal precipitation from geothermal fluid of $87 \mathrm{~N}-15 \mathrm{~T}$ production well in the Okuaizu geothermal field, Tohoku district, Japan. Mining Geol. 41, 231-242 (in Japanese).

Nitta, T., Suga, S., Tsukagoshi, S. and Adachi, M. (1987) Geothermal resources in the Okuaizu, Tohoku district, Japan. Chinetsu 24, 26-56 (in Japanese).

Nitta, T., Suga, S., Tsukagoshi, S. and Saiki, K. (1990) Recent development of geothermal energy in the Okuaizu field, Fukushima prefecture. Annual Meeting Geotherm. Res. Soc. Japan Abst., D-14 (in Japanese).

Sakai, H. and Matsubaya, O. (1974) Isotopic geochemistry of the thermal waters of Japan and its bearing on the Kuroko ore solutions. Econ. Geol. 69, 974-991.

Seki, Y. (1990a) Reservoir fluid chemistry at the Okuaizu geothermal field. Mining Geol. 40, 66 (in Japanese).

Seki, Y. (1990b) Gas concentration in aquifer fluid prior to boiling in the Oku-aizu geothermal system, Fukushima, Japan. Geochem. J. 24, 105-121.
Suzuki, K., Shimazu, M., Shimada, I. and Manabe, K. (1986) Route no. 28, Geological data of Cenozoic northeast Honshu arc, (Kitamura, N. ed.), 3 (in Japanese).

Takeno, N. (1988) Manual of pH estimation and chemical speciation code (PECS) for geothermal fluid. Geol. Surv. Japan Open File Rep. 49, 26p.

Takenouchi, S. (1985) Fluid inclusion in anhydrite and calcite from the Nishiyama geothermal area, Fukushima prefecture. J. Geotherm. Res. Soc. Japan 8, 191 (in Japanese).

Takenouchi, S. (1988a) Gas composition of fluid inclusion in anhydrite the Oku-aizu geothermal system, Fukushima prefecture. Abst. joint meeting of Soc. Min. Geol., Japan. Assoc. Pet. Min. Econ. Geol. and Miner. Soc. Japan 50 (in Japanese).

Takenouchi, S. (1988b) Fluid inclusion study at Okuaizu geothermal area. Abst. Internat. Symp. Geotherm. Ener, 1988. Explo. Devel. Geotherm. Res. 35-42.

Tanita, K., Komagata, S. and Mito, K. (1964) Fire clay resources in Sunagohara, Yanaizu town, Fukushima prefecture. Industrial Mineral Resources in the Tohoku Region, Japan 4, 114-121 (in Japanese).

Yamamoto, T. (in press) Chronology of the late Miocene-Pleistcene caldera volcanoes in the Aizu district, Northeast Japan. J. Geol. Soc. Japan 98.

Yoshida, Y. (1991) Geochemistry of the Nigorikawa geothermal system, southwest Hokkaido, Japan. Geochem. J. 25, 203-222 (this issue). 